\title{
Traditional Medicine Plant, Onopordum acanthium L. (Asteraceae): Chemical Composition and Pharmacological Research
}

\author{
Ekaterina Robertovna Garsiya ${ }^{1, *}$, Dmitryi Alexeevich Konovalov ${ }^{1}$, Arnold Alexeevich Shamilov ${ }^{1}$, \\ Margarita Petrovna Glushko ${ }^{1}$ and Kulpan Kenzhebaevna Orynbasarova ${ }^{2}$ \\ 1 Department of Pharmacognosy, Botany and Technology of Phytopreparations, \\ Pyatigorsk Medical-Pharmaceutical Institute (PMPI), Branch of Volgograd State Medical University, \\ Ministry of Health of Russia, Pyatigorsk 357532, Russia; d.a.konovalov@pmedpharm.ru (D.A.K.); \\ shamilovxii@yandex.ru (A.A.S.); perla21@yandex.ru (M.P.G.) \\ 2 South Kazakhstan State Pharmaceutical Academy, Shymkent 160019, Kazakhstan; kulpan_ok@mail.ru \\ * Correspondence: x-pharm@mail.ru; Tel.: +7-918-784-3403
}

Received: 10 December 2018; Accepted: 11 February 2019; Published: 12 February 2019

check for updates

\begin{abstract}
For many years, plants have been used in the traditional medicine of different cultures. The biennial plant of the family Asteraceae, Onopordum acanthium L., also known as Scotch thistle, is used in traditional medicine as an anti-inflammatory, antitumor, and cardiotonic agent. The plant is widespread in the world; it grows in Europe and Asia and was introduced to America and Australia. Stems and buds of the first-year plant are used in cooking as an analogue of artichoke in European cuisine. Additionally, inflorescences contain a complex of proteolytic enzymes "onopordosin", which may be used as a milk-clotting agent in the dairy industry. The chemical composition of the aerial part and roots of $O$. acanthium is represented by flavonoids, phenylpropanoids, lignans, triterpenoids, sesquiterpene lactones, and sterols. The anti-inflammatory, antiproliferative, and cardiotonic properties of the plant have been confirmed by pharmacological experiments with extracts and individual compounds using in silico, in vitro, and in vivo methods. This work is a review of information on the chemical composition and pharmacological studies of O. acanthium as a promising medicinal plant.
\end{abstract}

Keywords: Onopordum acanthium; Asteraceae; metabolites; pharmacology; antitumor; anti-inflammatory activity

\section{Introduction}

In 1503, the Scottish poet William Dunbar wrote an allegory for the wedding of King James IV and Princess Margaret Tudor, called "the Thistleand the Rose", where he presented James as a lion, eagle, and thistle, Margarita was presented as a rose. This allegory describes James (known as "James the just") as the lion, the guardian of peace in England and Scotland as the eagle and protector of men as the thistle. In Scotland, the prickly thistle (Onopordum acanthium L., Scotch thistle, cotton thistle) is known as a national symbol, although the common thistle (Cirsium vulgare (Savi) Ten.) is more often depicted [1].

The genus Onopordum includes about 50 species. The species $O$. acanthium L. is widely distributed. According to The Plant List [2], other names of O. acanthium are: Acanos spina Scop., Acanthium onopordon Gueldenst, Carduus acanthium (L.) Baill., Onopordum acanthium var. acanthium, and Onopordum acanthium subsp. acanthium. People of different countries refer to the plant as Scotch thistle, cotton thistle, heraldic thistle (English), eselsdistel, krebsdistel (German.), and chardon aux ânes 
(French). In Greek, the genus name translates as onos - donkey, as pordon — carminative, acanthium species name comes from the Greek word meaning "prickly".

According to the taxonomy of vascular plants of A. L. Takhtajan [3], O. acanthium belongs to the family Asteraceae, subfamily Carduoideae (Lactucoideae), tribe Cardueae, subtribe Carduinae, genus Onopordum L., and section Onopordum. The superfamily taxonomy consists of the kingdom Plantae, subkingdom Viridiplantae, infrakingdom Streptophyta, superdivision Embryophyta, division Tracheophyta, subdivision Spermatophyta, class Magnoliopsida, superorder Asteranae, and order Asterales [4]. The modern systematics of vascular plants (Angiosperm Phylogeny Group, APG) are based on the comparison of gene sequences in chloroplasts and ribosomes. Last updated in 2016, the APG IV uses hoards in which all taxa in a hierarchical sequence have only one-to-one correspondence. The family Asteraceae corresponds to the clade Asterids, order Asterales Link [5].

There are two independent subspecies of O. acanthium: Onopordum acanthium subsp. ceretanum (Sennen) Arènes and Onopordum acanthium subsp. gautieri (Rouy) Bonnier [2].

\section{Methodology of Review}

We used scientific databases, such as PubMed, ScienceDirect, Mendeley, ResearchGate, and Google Scholar. Research was carried out using the keywords "onopordum", "acanthium", "thistle", and "onopordon". We obtained about 600 references according to these key words. Bibliographic data were managed using the Zotero 5.0.60 software (Center for History and New Media at George Mason University, Virginia, USA). References relating to Onopordum acanthium L. consist of 103 English and 53 Russian sources including common references (six English and 13 Russian), patents (14 Russian), botanical characteristics (six English and three Russian), chemical and pharmacological studies (42 English and 20 Russian), ecological and biological works (35 English and two Russian), industrial studies (six English and one Russian), and reviews about traditional medicinal practice (eight English). All data were statistically analyzed in corresponding articles.

\section{Botanical Characteristics}

O. acanthium L. is a biennial herb that grows to $50-200 \mathrm{~cm}$ in height. The radix is thick and succulent above $30 \mathrm{~cm}$. The stem is upright, branching, has wings less than $1.5 \mathrm{~cm}$ wide with spines on the edge. The stem is round and $2-3 \mathrm{~cm}$ in diameter. The first-year plants grow in a rosette of leaves, and there are broad, elliptic lanates on both sides. In the second year, the plants flower, bear fruits, and die. The rosette leaves are elliptic and broad and have petioles and lanates on both sides. The stem leaves are smaller, sessile, and oblong. All leaves have stout yellow spines on the edge and thick pubescence. On the bottom of stems there are one or several inflorences. Capitula are globular, have spiny involucre which contain green leaves with yellow hard spines on the ends. The receptacle is alveolate. The calyx consists of hairs. The corolla is purple and flowers are hermaphrodite. The achenes are brown and obovate and have ribs on the surface and redhead pappuses which are twice as long as the achenes [6].

O. acanthium blooms in June-September and achenes ripen in July-October. The plant grows on stone or sandy soil rich in ammonium salts in light open areas [7].

\section{Ethnomedical Usage}

O. acanthium is is used in Europe as an edible plant. Roots, shoots, and inflorescences of first-year plants are used as a substitute for artichoke [8]. In Patagonia, Argentina, thistle is pollinated by Apis mellifera L. and is a source of honey. The plant is also an edible culture for goats and sheep [7].

In folk medicine, O. acanthium is used for the treatment of different types of cancer. Additionally, the powder, juice, and decoction of the aerial part of the plant is known as a diuretic, to treat nervousness. Furthermore, O. acanthium may stimulate the central nervous system and has cardiotonic and haemostatic properties [9]. Moreover, the infusion of leaves and inflorescences decreases edema of various etiologies [10]. 
O. acanthium and O. illyricum are noted in De Materia Medica in Volume III, "roots, semina and herbs", by Berendes [11]. The fresh herb of "Cardvi tomentosi" was first mentioned in the Russian Pharmacopeia (Pharmacopoea Rossica, 1798) [12]. In the Encyclopedia of Traditional Chinese Medicines [13], O. acanthium is described as a source of onopordopicrin and eriodictyol. Also, the aerial part of the plant is used as a hemostatic agent.

In homeopathy, $O$. acanthium is a component of cardiotonic remedy. Flowers of O. acanthium and Primula veris L. and leaves of Hyoscyamus niger L. are used in Primula comp. (WALA-R, subsidiary of WALA Heilmittel GmbH, Moscow, Russia) in granules. Another composition is Cardiodoron ${ }^{\circledR}$ Trophen. There are drops with ethanol extracts of fresh flowers of O. acanthium and P. veris and fresh herb of $H$. niger. These drugs are used in cardiovascular diseases and as sedative agents [14-18]. Gattefossé (Saint-Priest, France) has developed a cosmetic preparation containing alcohol extracts from flowers, leaves, and stems $O$. acanthium. This product may be used in creams and ointments and has moisturizing and anti-aging properties due to epidermal restructuring activity [19].

\section{Chemical Composition}

Compounds of phenol, triterpene, and steroid structures are detected in the aerial part of O. acanthium. Additionally, the composition of fat oil has been studied in the seeds. Sesquiterpene lactones and polyacetylenes are found in the roots.

\subsection{Phenols}

An inhibitor of angiotensin-converting enzyme (ACE) was isolated from methanol extract of achenes in an amount of $70 \mathrm{mg}$ from $100 \mathrm{~g}$ achenes. It is 1, (E)-1-oxo-3,4-dihydro-1 H-isochromen-7-yl 3-(3,4-dihydroxyphenyl) acrylate (Figure 1) [20].<smiles>O=C(/C=C/c1ccc(O)c(O)c1)Oc1ccc2c(c1)C(=O)OCC2</smiles>

Figure 1. Inhibitor of angiotensin-converting enzyme (ACE) isolated from achenes of Onopordum acanthium, 1, (E)-1-oxo-3,4-dihydro-1 H-isochromen-7-yl 3-(3,4-dihydroxyphenyl) acrylate.

Kos [21] investigated the phenol and flavonoid contents of methanol, ethanol, and acetone extracts of flowers and leaves of O. acanthium L., Carduus acanthoides L., Cirsium arvense (L) Scop., and Centaurea solstitialis L. from the family Asteraceae. The content of phenols in flowers of O. acanthium was $19.71 \mathrm{mg}$ of gallic acid/L of ethanol extract, $24.70 \mathrm{mg}$ of gallic acid/L of methanol extract, $13.94 \mathrm{mg}$ of gallic acid/L of acetone extract. The content of phenols in the leaves of O. acanthium was $26.34 \mathrm{mg}$ of gallic acid/L of ethanol extract, $30.47 \mathrm{mg}$ of gallic acid/L of methanol extract, and $36.67 \mathrm{mg}$ of gallic acid/L of acetone extract.

Habibatni [22] also determined the content of phenols in butanol extract of $O$. acanthium leaves (8.96 mg of gallic acid/100 mg of dry extract).

\subsubsection{Flavonoids}

Flavones, flavonols, and flavanones aglycons have been described in O. acanthium. Glycoside forms of apigenin, quercetin, and luteolin have been discovered in the aerial part of the plant (Table 1) [23].

Apigenin and luteolin were isolated from the aerial part of $O$. acanthium in the amount of $4.5 \mathrm{mg}$ per $4.4 \mathrm{~kg}$ of dry raw materials. They are also found in the leaves and flowers [22-25]. 
Table 1. Flavonoids from Onopordum acanthium L.

\begin{tabular}{|c|c|c|c|c|c|c|c|}
\hline No & Name & $\mathbf{R}^{1}$ & $\mathbf{R}^{2}$ & $\mathbf{R}^{3}$ & $\mathbf{R}^{4}$ & $\mathbf{R}^{5}$ & $R^{6}$ \\
\hline 1. & Apigenin & $\mathrm{OH}$ & $\mathrm{H}$ & $\mathrm{OH}$ & $\mathrm{H}$ & $\mathrm{H}$ & $\mathrm{OH}$ \\
\hline 2. & Luteolin & $\mathrm{OH}$ & $\mathrm{H}$ & $\mathrm{OH}$ & $\mathrm{H}$ & $\mathrm{OH}$ & $\mathrm{OH}$ \\
\hline 3. & Scutellarein & $\mathrm{OH}$ & $\mathrm{OH}$ & $\mathrm{OH}$ & $\mathrm{H}$ & $\mathrm{H}$ & $\mathrm{OH}$ \\
\hline 4. & Nepetin & $\mathrm{OH}$ & $\mathrm{OCH}_{3}$ & $\mathrm{OH}$ & $\mathrm{H}$ & $\mathrm{OH}$ & $\mathrm{OH}$ \\
\hline 5. & Chrysoeriol & $\mathrm{OH}$ & $\mathrm{H}$ & $\mathrm{OH}$ & $\mathrm{H}$ & $\mathrm{OCH}_{3}$ & $\mathrm{OH}$ \\
\hline 6. & Hispidulin & $\mathrm{OH}$ & $\mathrm{OCH}_{3}$ & $\mathrm{OH}$ & $\mathrm{H}$ & $\mathrm{H}$ & $\mathrm{OH}$ \\
\hline 7. & Pectolinarigenin & $\mathrm{OH}$ & $\mathrm{OCH}_{3}$ & $\mathrm{OH}$ & $\mathrm{H}$ & $\mathrm{H}$ & $\mathrm{OCH}_{3}$ \\
\hline 8. & Scutellarein $4^{\prime}$-methyl ether & $\mathrm{OH}$ & $\mathrm{OH}$ & $\mathrm{OH}$ & $\mathrm{H}$ & $\mathrm{H}$ & $\mathrm{OCH}_{3}$ \\
\hline 9. & Quercetin & $\mathrm{OH}$ & $\mathrm{H}$ & $\mathrm{OH}$ & $\mathrm{OH}$ & $\mathrm{OH}$ & $\mathrm{OH}$ \\
\hline 10. & Apigenin-7-O-glucoside & $\mathrm{OH}$ & $\mathrm{H}$ & O-glucose & $\mathrm{H}$ & $\mathrm{H}$ & $\mathrm{OH}$ \\
\hline 11. & Apigenin-7-O-rutinoside & $\mathrm{OH}$ & $\mathrm{H}$ & O-rutinose & $\mathrm{H}$ & $\mathrm{H}$ & $\mathrm{OH}$ \\
\hline 12. & Apigenin-7-O- $\beta$-D-glucuronide & $\mathrm{OH}$ & $\mathrm{H}$ & O-glucuronic acid & $\mathrm{H}$ & $\mathrm{H}$ & $\mathrm{OH}$ \\
\hline 13. & Luteolin-7-O-glucoside & $\mathrm{OH}$ & $\mathrm{H}$ & O-glucose & $\mathrm{H}$ & $\mathrm{OH}$ & $\mathrm{OH}$ \\
\hline 14. & Quercetin-3-O-glucoside & $\mathrm{OH}$ & $\mathrm{H}$ & $\mathrm{OH}$ & O-glucose & $\mathrm{OH}$ & $\mathrm{OH}$ \\
\hline 15. & Isorhamnetin-3-O-glucoside & $\mathrm{OH}$ & $\mathrm{H}$ & $\mathrm{OH}$ & O-glucose & $\mathrm{OCH}_{3}$ & $\mathrm{OH}$ \\
\hline
\end{tabular}

4'-methyl ether of scutellarein (6-hydroxy apigenin) was found in leaves in the amount of $9.5 \mathrm{mg}$ per $215 \mathrm{~g}$ of dry leaves [26]. Other methoxy derivatives (nepetin, chrysoeriol, hispidulin, pectolinarigenin) were detected in the aerial part in the amount of $8.0 \mathrm{mg} / 4.4 \mathrm{~kg}$ dry raw material (nepetin), $3.5 \mathrm{mg} / 4.4 \mathrm{~kg}$ dry raw material (hispidulin), as well as in leaves and $1.6 \mathrm{mg} / 215 \mathrm{~g}$ dry weight (pectolinarigenin) and flowers (chrysoeriol) [23-26].

Eriodictyol and quercetin were identified in flowers [23]. Apigenin, luteolin, and quercetin glycosides were found in herb, while anthocyanin cyanin was found in flowers (Figure 2) [23,27,28].<smiles>O=C1CC(c2ccc(O)c(O)c2)Oc2cc(O)cc(O)c21</smiles>

(a)

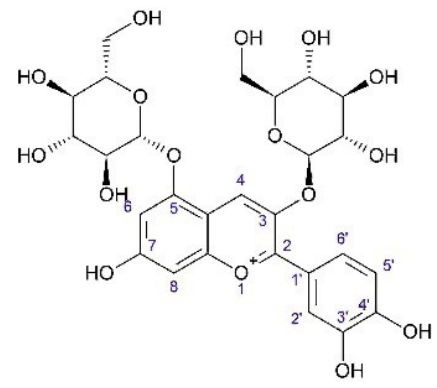

(b)

Figure 2. Flavanone and antocyanin from O. acanthium L.: (a) Eriodictyol; (b) Cyanin.

Kos [21] measured the content of flavonoids in several extracts of flowers and leaves of $O$. acanthium. In flowers, the content was $30.37 \mathrm{mg}$ of quercetin/L of ethanol extract, $42.09 \mathrm{mg}$ of quercetin/L of methanol extract, and $32.40 \mathrm{mg}$ of quercetin/L of acetone extract. The content of flavonoids in the leaves of $O$. acanthium was $40.06 \mathrm{mg}$ of quercetin/L of ethanol extract, $53.18 \mathrm{mg}$ of quercetin/L of methanol extract, and $85.37 \mathrm{mg}$ of quercetin/L of acetone extract.

Habibatni [22] determined the flavonoid content in butanol extract of $O$. acanthium leaves $(3.93 \mathrm{mg}$ of catechin/100 mg of dry extract). 


\subsubsection{Phenylpropanoides}

Capitula accumulate caffeic and chlorogenic acids [23]. Methanol extract from achenes contains $10.2 \pm 0.2 \%$ (by volume) or $3.5 \pm 0.4 \mathrm{mg} / \mathrm{g}$ of fresh seeds of isochlorogenic acid [29]. Phenylpropanoid aconiside was isolated from dry achenes in chloroform extract [30] (Figure 3).

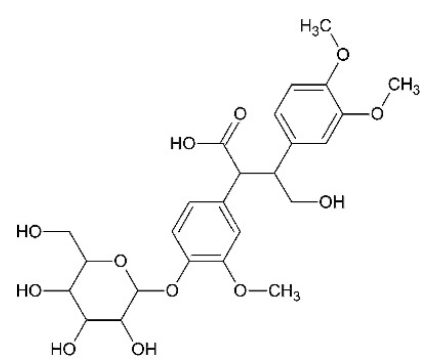

(a)

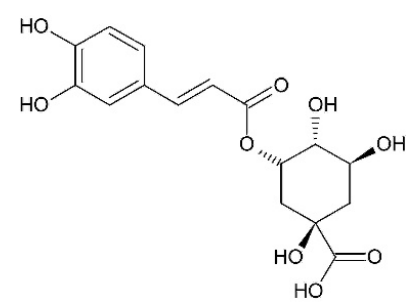

(b)<smiles>O=C(O)/C=C/c1ccc(O)c(O)c1</smiles>

(c)

Figure 3. Phenylpropanoids from O. acanthium L.: (a) Aconiside; (b) Isochlorogenic acid; (c) Caffeic acid.

\subsubsection{Lignans}

Lajter $[24,25,31]$ isolated lignans such as pinoresinol ( $5.5 \mathrm{mg} / 4.4 \mathrm{~kg}$ air-dried herb), syringaresinol (9.4 mg/4.4 kg air-dried herb) and medioresinol (3.4 mg/4.4 kg air-dried herb) (Table 2).

Table 2. Bis-epoxy forms of lignans from O. acanthium $\mathrm{L}$.

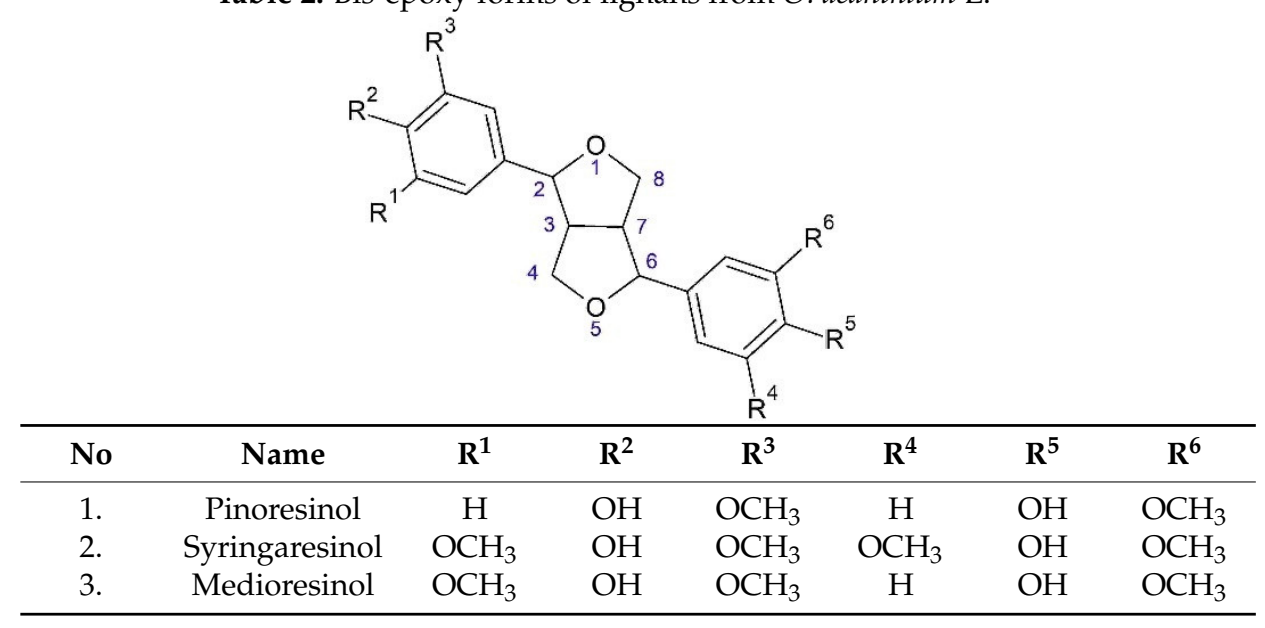

The roots of O. acanthium contain nitidanin diisovalerianate [24,25,31]. Daci [29] found in methanol extract of achenes $87 \pm 2 \%$ (by volume) or $38.0 \pm 3.2 \mathrm{mg} / \mathrm{g}$ of fresh fruits of arctiin (Figure 4).<smiles>COc1cc(C2Oc3cc(/C=C/COC(=O)CC(C)C)cc(OC)c3OC2COC(=O)CC(C)C)cc(OC)c1O</smiles>

(a)<smiles>COc1ccc(C[C@@H]2COC(=O)[C@@H]2Cc2ccc(OC3O[C@H](CO)[C@@H](O)[C@H](O)[C@H]3O)c(OC)c2)cc1OC</smiles>

(b)

Figure 4. Lignans from O. acanthium L.: (a) Nitidanin diisovalerianate; (b) Arctiin. 


\subsubsection{Coumarins}

Bogs and Bogs [27] detected aesculin and aesculetin in herb of O. acanthium L. (Figure 5).<smiles>O=c1ccc2cc(O[C@@H]3C(O)[C@@H](O)[C@H](O)[C@@H](CO)C3O)c(O)cc2o1</smiles>

(a)<smiles>O=c1ccc2cc(O)c(O)cc2o1</smiles>

(b)

Figure 5. Coumarins from O. acanthium L.: (a) Aesculin; (b) Aesculetin.

\subsection{Terpenoids}

Different parts of O. acanthium L. contain sesquiterpene lactones and triterpenoids.

Ivanova [32] detected iridoids in the herb of O. acanthium, including harpagide. There were $5.76 \%$ of iridoids in the O. acanthium herb.

\subsubsection{Sesquiterpene Lactones}

Parts of $O$. acanthium contain derivatives of elemane, germacrane, eudesmane, and guaiane. These compounds may play roles in the antitumor activity of $O$. acanthium.

\section{Guaianolides}

In a review article [33] of the genus Onopordum, derivatives of guaiane are described: $4 \beta, 15$-dihydro-3-dehydrozaluzanin C (estafiatone), zaluzanin C, and $4 \beta, 15,11 \beta, 13$-tetrahydrozaluzanin $\mathrm{C}$ (dihydroestafiatone) in O. laconicum.

Csupor-Löffler [31] isolated these lactones from roots of O. acanthium (Table 3).

Table 3. Guianolides from O. acanthium L.

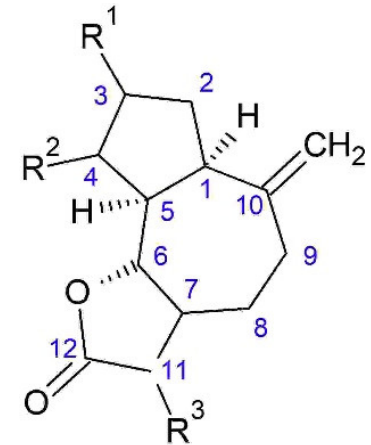

\begin{tabular}{ccccc}
\hline No & Name & $\mathbf{R}^{\mathbf{1}}$ & $\mathbf{R}^{\mathbf{2}}$ & $\mathbf{R}^{\mathbf{3}}$ \\
\hline 1. & $4 \beta, 15$-dihydro-3-dehydrozaluzanin $\mathrm{C}$ & $-\mathrm{HC}(\mathrm{O})$ & $\alpha-\mathrm{CH}_{3}$ & $\mathrm{CH}_{2}$ \\
2. & Zaluzanin C & $\mathrm{OH}$ & $\mathrm{CH}_{2}$ & $\mathrm{CH}_{2}$ \\
3. & $4 \beta, 15,11 \beta, 13$-tetrahydrozaluzanin $\mathrm{C}$ & $\beta-\mathrm{OH}$ & $\alpha-\mathrm{CH}_{3}$ & $\beta-\mathrm{CH}_{3}$ \\
\hline
\end{tabular}

Germacranolides

Droźdź [34] isolated onopordopicrin from fresh leaves of O. acanthium. A total of $3.5 \mathrm{~g}$ of onopordopicrin was obtained from $10 \mathrm{~kg}$ of fresh leaves using water extract and purification with chloroform. Later, onopordopicrin was isolated from leaves [35]. Arctiopicrin was also found in O. acanthium herb (Figure 6) [27]. 


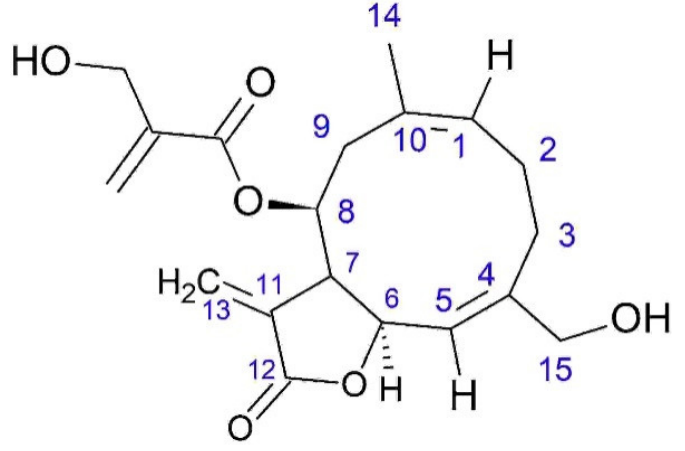

(a)

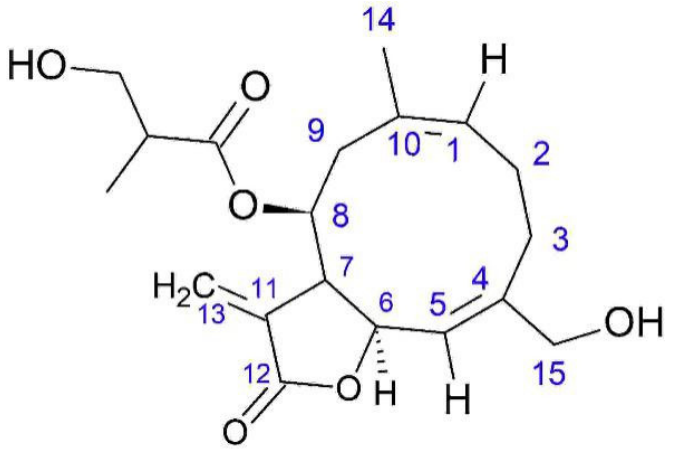

(b)

Figure 6. Germacranolides from O. acanthium L.: (a) Onopordopicrin; (b) Arctiopicrin.

Elemanolides and Eudesmanolides

Watanabe [26] associated the widespread use of O. acanthium with allelopathy. As chemical agents, flavonoids such as pectolinarigenin (1), scutellarein 4'-methyl ether (2), two sesquiterpene lactones elemanolide 11(13)-dehydromelitensin $\beta$-hydroxyisobutyrate (3) and acanthiolide (4) (Figure 7) were found in leaves. Allelopathy was observed by the inhibition of wheat coleoptile intergrowth. The most active component was lactone 3 (half maximal inhibitory concentration $\left(\mathrm{IC}_{50}\right)=1.794 \times 10^{-4} \mathrm{mg} / \mathrm{mL}$ ), followed by pectolinarigenin $\left(\mathrm{IC}_{50}=1.263 \times 10^{-3} \mathrm{mg} / \mathrm{mL}\right.$ ), while scutellarein $4^{\prime}$-methyl ether was less active $\left(\mathrm{IC}_{50}=1.709 \times 10^{-3} \mathrm{mg} / \mathrm{mL}\right)$. Component 4 was produced in a small amount, and its activity was not investigated. The yields of compounds 3 and 4 were $2.2 \mathrm{mg}$ and $0.9 \mathrm{mg}$, respectively, from $215 \mathrm{~g}$ of air-dried leaves.

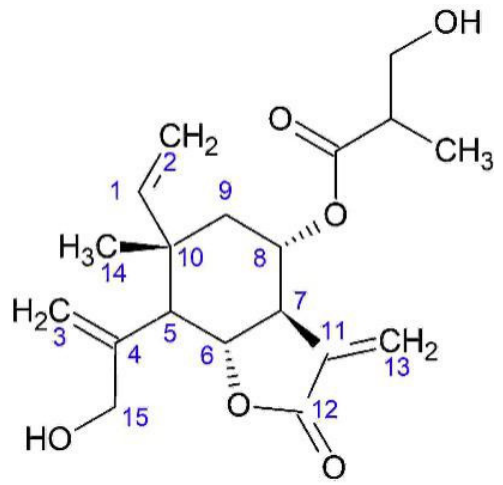

(a)

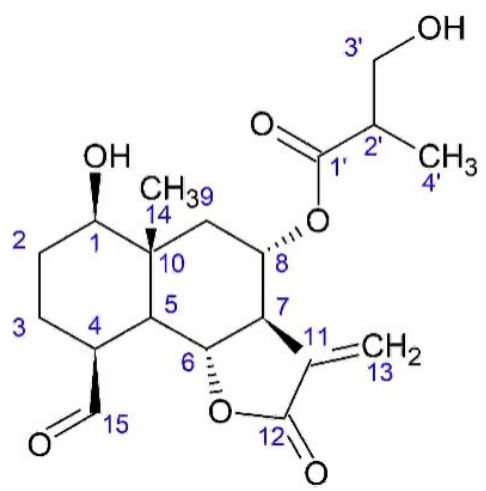

(b)

Figure 7. Elemanolide and eudesmanolide from O. acanthium L.: (a) Elemanolide 11(13)-dehydromelitensin $\beta$-hydroxyisobutyrate; (b) Acanthiolide.

\subsubsection{Triterpene Alcohols}

Khalilov et al. isolated triterpene alcohols- $\alpha$ - and $\beta$-amyrin, lupeol, and triterpenoid taraxasterol-and their acetates from the leaves, stems, flowers, parts of capitula and achenes of O. acanthium (Figure 8). Air-dried plant material was crushed and then extraction by chloroform was performed in the ratio 1:4. The residue after chloroform evaporation was extracted by $70 \%$ ethanol. Polar compounds and chloroform residue were separated in a column with silica gel impregnated with silver nitrate. There were three fractions: fraction A included the amount of higher alkanes, fraction $B$ contained a mixture of triterpene alcohols, and fraction $C$ contained individual compounds such as taraxasterol or taraxasteryl acetate. Acetate accumulates most in reproductive plant parts. The structure of substances was defined by the methods of ${ }^{1} \mathrm{H}$ - and ${ }^{13} \mathrm{C}$ nuclear magnetic resonance (NMP). There was found to be $0.1 \%$ of taraxasterol in air-dried flowers, $1.0 \%$ in leaves, and $0.1 \%$ 
in stems. Leaves were found to contain $0.08 \%$ of taraxasteryl acetate, stems $0.05 \%$, flowers $0.3 \%$, receptacles $2.8 \%$, leaves of involucre $0.13 \%$, pappus of achenes $0.7 \%$, and roots $0.1 \%$. Lupeol and $\alpha$-amyrin and their acetates were found in fat oil of achenes, which was isolated by extraction with hexane [36-39].

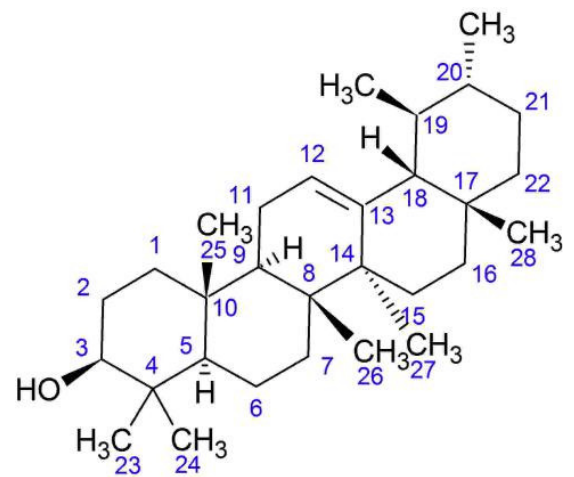

(a)

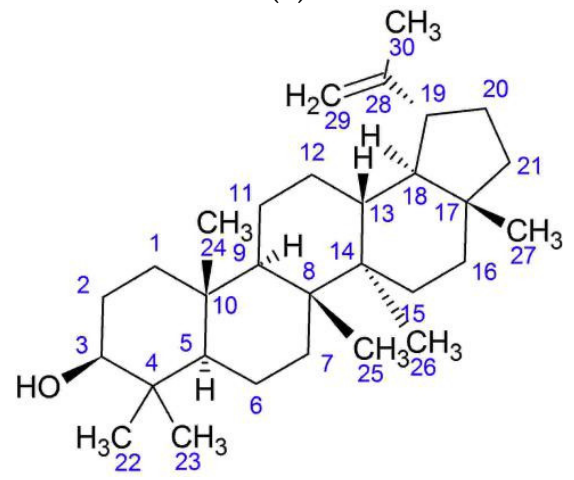

(c)

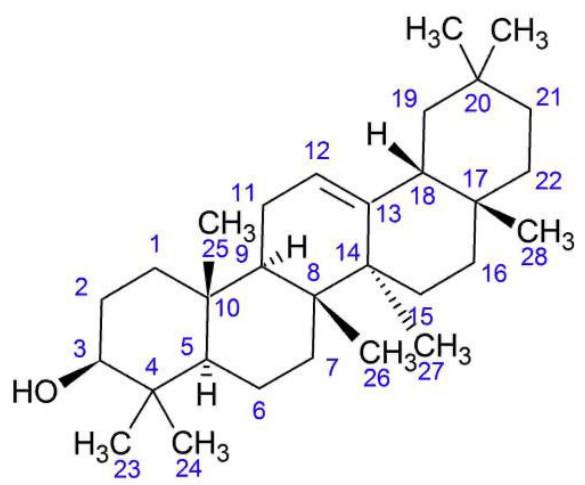

(b)

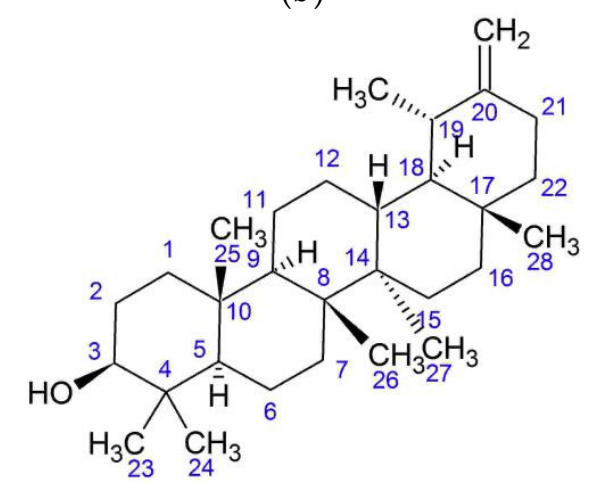

(d)

Figure 8. Triterpenoids from O. acanthium L.: (a) $\alpha$-amyrin; (b) $\beta$-amyrin; (c) Lupeol; (d) Taraxasterol.

\subsection{Steroids}

Nolasco [40] detected in achenes $\Delta^{5}$ avenasterol, campesterol, stigmasterol, $\beta$-sitosterol, brassicasterol, and cholesterol. Another work [41] described the presence in achenes of O. acanthium phytosterols such as derivative of 4-desmethylsterol (campesterol, stigmasterol, $\beta$-sitosterol, $\Delta^{7}$ sitosterol, $\Delta^{7}$ avenasterol). Authors also investigated the dynamics of phytosterol accumulation during three periods (days after flowering, DAF). The first period included 5-14 DAF, the second period 14-38 DAF, and the third period 38-45 DAF. Stigmasterol in the amount of $10.48 \pm 1.47 \%$ from all sterols was accumulated at $14 \mathrm{DAF}$, followed by campesterol (10.37 $\pm 0.36 \%$ at $14 \mathrm{DAF})$, stigmastanol $(4.86 \pm 0.22 \%$ at $38 \mathrm{DAF})$, and $\Delta^{7}$ sitosterol $(10.43 \pm 0.51 \%$ at $45 \mathrm{DAF})$. The main component was $\beta$-sitosterol (77.79 $\pm 0.4 \%$ in all sterols or $632 \mathrm{~g} / \mathrm{kg}$ air-dried achenes). The total amount of sterols in achenes was $25 \mathrm{~g} / \mathrm{kg}$, and $5 \mathrm{~g} / \mathrm{kg}$ in oil [42].

In fatty oil, free sterols were found: $\beta$-sitosterol, campesterol, traces of sitosterol and stigmasterol [39]. In roots, stigmasterol, $\beta$-sitosterol, and 24-methylenecholesterol were found (Table 4) [24,25,31]. 
Table 4. Steroids from O. acanthium L.

\begin{tabular}{|c|c|c|c|}
\hline No & Name & $\mathbf{R}^{1}$ & $\Delta$ \\
\hline 1. & $\Delta^{5}$ avenasterol & $-\mathrm{CH}\left(\alpha-\mathrm{CH}_{3}\right)-\mathrm{CH}_{2}-\mathrm{CH}_{2}-\mathrm{C}\left(\mathrm{CH}\left(\mathrm{CH}_{3}\right)_{2}\right)=\mathrm{CH}-\mathrm{CH}_{3}$ & 5 \\
\hline 2. & $\Delta^{7}$ avenasterol & $-\mathrm{CH}\left(\alpha-\mathrm{CH}_{3}\right)-\mathrm{CH}_{2}-\mathrm{CH}_{2}-\mathrm{C}\left(\mathrm{CH}\left(\mathrm{CH}_{3}\right)_{2}\right)=\mathrm{CH}-\mathrm{CH}_{3}$ & 7 \\
\hline 3. & Campesterol & $-\mathrm{CH}\left(\alpha-\mathrm{CH}_{3}\right)-\mathrm{CH}_{2}-\mathrm{CH}_{2}-\mathrm{CH}\left(\alpha-\mathrm{CH}_{3}\right)-\mathrm{CH}\left(\mathrm{CH}_{3}\right)-\mathrm{CH}_{3}$ & 5 \\
\hline 4. & $\Delta^{7}$ campesterol & $-\mathrm{CH}\left(\alpha-\mathrm{CH}_{3}\right)-\mathrm{CH}_{2}-\mathrm{CH}_{2}-\mathrm{CH}\left(\beta-\mathrm{CH}_{3}\right)-\mathrm{CH}\left(\mathrm{CH}_{3}\right)-\mathrm{CH}_{3}$ & 7 \\
\hline 5. & Stigmasterol & $-\mathrm{CH}\left(\alpha-\mathrm{CH}_{3}\right)-\mathrm{CH}=\mathrm{CH}-(\alpha) \mathrm{CH}\left(\mathrm{C}_{2} \mathrm{H}_{5}\right)-\mathrm{CH}(\mathrm{CH} 3)-\mathrm{CH}_{3}$ & 5 \\
\hline 6. & $\Delta^{7}$ stigmasterol & $-\mathrm{CH}\left(\alpha-\mathrm{CH}_{3}\right)-\mathrm{CH}=\mathrm{CH}-(\alpha) \mathrm{CH}\left(\mathrm{C}_{2} \mathrm{H}_{5}\right)-\mathrm{CH}\left(\mathrm{CH}_{3}\right)-\mathrm{CH}_{3}$ & 5,7 \\
\hline 7. & Stigmastanol & $-\mathrm{CH}\left(\alpha-\mathrm{CH}_{3}\right)-\mathrm{CH}_{2}-\mathrm{CH}_{2}-(\alpha) \mathrm{CH}\left(\mathrm{C}_{2} \mathrm{H}_{5}\right)-\mathrm{CH}\left(\mathrm{CH}_{3}\right)-\mathrm{CH}_{3}$ & - \\
\hline 8. & $\beta$-sitosterol & $-\mathrm{CH}\left(\alpha-\mathrm{CH}_{3}\right)-\mathrm{CH}_{2}-\mathrm{CH}_{2}-(\alpha) \mathrm{CH}\left(\mathrm{C}_{2} \mathrm{H}_{5}\right)-\mathrm{CH}\left(\mathrm{CH}_{3}\right)-\mathrm{CH}_{3}$ & 5 \\
\hline 9. & Brassicasterol & $-\mathrm{CH}\left(\alpha-\mathrm{CH}_{3}\right)-\mathrm{CH}=\mathrm{CH}-\mathrm{CH}\left(\beta-\mathrm{CH}_{3}\right)-\mathrm{CH}\left(\mathrm{CH}_{3}\right)-\mathrm{CH}_{3}$ & 5 \\
\hline 10. & $\Delta^{7}$ sitosterol & $-\mathrm{CH}\left(\alpha-\mathrm{CH}_{3}\right)-\mathrm{CH}_{2}-\mathrm{CH}_{2}-(\alpha) \mathrm{CH}\left(\mathrm{C}_{2} \mathrm{H}_{5}\right)-\mathrm{CH}\left(\mathrm{CH}_{3}\right)-\mathrm{CH}_{3}$ & 7 \\
\hline 11. & Cholesterol & $-\mathrm{CH}\left(\alpha-\mathrm{CH}_{3}\right)-\mathrm{CH}_{2}-\mathrm{CH}_{2}-\mathrm{CH}_{2}-\mathrm{CH}\left(\mathrm{CH}_{3}\right)-\mathrm{CH}_{3}$ & 5 \\
\hline 12. & 24-methylenecholesterol & $-\mathrm{CH}\left(\alpha-\mathrm{CH}_{3}\right)-\mathrm{CH}_{2}-\mathrm{CH}_{2}-\mathrm{C}\left(\mathrm{CH}\left(\mathrm{CH}_{3}\right)_{2}\right)=\mathrm{CH}_{2}$ & 5 \\
\hline
\end{tabular}

\subsection{Polyacetylenes}

Bohlmann [43] detected polyacetylenes in the roots of O. acanthium (Table 5).

Table 5. Polyacetylenes from O. acanthium L.

\begin{tabular}{|c|c|c|}
\hline No & Name & Structure \\
\hline 1. & Heptadecatetraen-(2, 8, 10, 16)-diin-(4, 6)-al-(1) & $(2 \mathrm{E}, 8 \mathrm{E}, 10 \mathrm{E}) \mathrm{CH}(\mathrm{O})-\mathrm{CH}=\mathrm{CH}-(\mathrm{C} \equiv \mathrm{C})_{2}-(\mathrm{CH}=\mathrm{CH})_{2}-\left(\mathrm{CH}_{2}\right)_{4}-\mathrm{CH}=\mathrm{CH}_{2}$ \\
\hline 2. & Tridecadien-(1, 11)-tetrain- $(3,5,7,9)$ & $\mathrm{CH}_{3}-\mathrm{CH}=\mathrm{CH}-(\mathrm{C} \equiv \mathrm{C})_{4}-\mathrm{CH}=\mathrm{CH}_{2}$ \\
\hline 3. & Heptadecatetraen-(1, 7, 9, 15)-diin-(11, 13) & $(7 \mathrm{E}, 9 \mathrm{E}, 15 \mathrm{E}) \mathrm{CH}_{3}-\mathrm{CH}=\mathrm{CH}-(\mathrm{C} \equiv \mathrm{C})_{2}-(\mathrm{CH}=\mathrm{CH})_{2}-\left(\mathrm{CH}_{2}\right)_{4}-\mathrm{CH}=\mathrm{CH}_{2}$ \\
\hline 4. & Heptadecatetraen-(2, 8, 10, 16)-diin-(4, 6)-ol-(1) & $(2 \mathrm{E}, 8 \mathrm{E}, 10 \mathrm{E}) \mathrm{HO}-\mathrm{CH}_{2}-\mathrm{CH}=\mathrm{CH}-(\mathrm{C} \equiv \mathrm{C})_{2}-(\mathrm{CH}=\mathrm{CH})_{2}-\left(\mathrm{CH}_{2}\right)_{4}-\mathrm{CH}=\mathrm{CH}_{2}$ \\
\hline
\end{tabular}

\subsection{Fatty Acids}

Ul'chenko [39,44-48] isolated fatty oil from $100 \mathrm{~g}$ of achenes by extraction with hexane at room temperature. Substances from the husks of cypselae were extracted by petroleum ether $\left(40-60^{\circ} \mathrm{C}\right)$. The division on fractions was performed in a column with silica gel. There were nine fractions of glycerids, with the main fraction consisting of triglycerides (88.0\%). Alkaline hydrolysis with potassium hydroxide in methanol and enzyme hydrolysis with pancreatic lipase were carried out. To detect fatty acids and triglycerid transesterification in methanol, gas-liquid chromatography was carried out. The chemical structure of lipophilic components was identified with infrared (IR)- and NMR spectrometry.

Arfaoui [41] investigated the dynamics of fatty acid accumulation in achenes during three phases. The main fatty acids in oil from O. acanthium are linoleic, oleic, palmitic, stearic, and pentadecanoic acids. In contrast, epoxy-, hydroxy acids were not found in the work of Ul'chenko et al. The total amount of saturated and unsaturated acids in mature seeds was found to be $0.11-2.23 \mathrm{mg} / \mathrm{g}$.

Matthaus [49] collected seeds of O. acanthium in Konya Province in Turkey. Mature seeds contained $15.71 \%$ of crude oil. The main fatty acids were linoleic $(65.9 \%)$, oleic $(18.8 \%)$, palmitic $(5.8 \%)$, and stearic $(2.6 \%)$ acids.

Zhelev [42] investigated fatty oil of Carduus thoermeri Weinm., O. acanthium L. and Silybum marianum L. from Bulgaria. The main fatty acids in the oil of $O$. acanthium were linoleic $(576.5 \mathrm{~g} / \mathrm{kg})$, oleic $(287.9 \mathrm{~g} / \mathrm{kg})$, palmitic $(88.1 \mathrm{~g} / \mathrm{kg})$, and stearic $(39.5 \mathrm{~g} / \mathrm{kg})$ acids. In comparison with this, the work of Tonguç [50] described a smaller amount of fatty acids (212 g/ kg vs. $144 \mathrm{~g} / \mathrm{kg})$. Additionally, linoleic and linolenic acids were detected in the leaves of O. acanthium [35]. 
In those works, epoxy acids such as vernolic and coronaric acids were identified; saturated acids such as hentriacontanoic, nonacosanoic, stearic, palmitic, arachidic, pentadecanoic, margaric, myristic, and behenic acids; unsaturated acids with one double bond such as palmitoleic, oleic, gadoleic, erucic, and vaccenic acids; and polyunsaturated acids such as linoleic acid. Furthermore, 13-oxo-9Z,11E-octadecadienoic acid was found in roots [24,31].

\subsection{Tocols}

Matthaus [49] found tocopherols in fatty oil of achenes of O. acanthium; present was $\alpha$-tocopherol (24.7 mg/100 g of oil); $\alpha$-tocotrienol $(1.1 \mathrm{mg} / 100 \mathrm{~g}$ of oil), $\beta$-tocopherol $(0.4 \mathrm{mg} / 100 \mathrm{~g}$ of oil), and $\gamma$-tocopherol $(0.2 \mathrm{mg} / 100 \mathrm{~g}$ of oil). Moreover, Zhelev [42] detected $\alpha$-tocopherol $(911 \mathrm{~g} / \mathrm{kg}$ of oil), $\alpha$-tocotrienol ( $89 \mathrm{~g} / \mathrm{kg}$ of oil).

\subsection{Nitrogen-Containing Compounds}

Leaves of $O$. acanthium were found to contain $0.05 \%$ of alkaloids, and achenes were found to contain $0.1 \%$ of alkaloids [51]. In herb, 1-amino-2-propanol [52] and stachydrine [27] were found. Furthermore, in flowers, choline was detected [23]. The composition of amino acids was also determined [23].

\subsection{Other Components}

Muhamedov [53] determined the content of phospholipids and phytin in seeds of O. acanthium. Seeds were degreased with acetone, and phospholipids were extracted by chloroform-methanol (2:1). Dried extract was purified with acetone. The residue in the extract was dissolved in a mixture of chloroform-methanol-water (90:10:1), and then phospholipids were purified by size-exclusion chromatography and weighed. Quality analysis of phospholipids was carried out by thin layer chromatography (TLC). Phytin was extracted by $1 \%$ nitric acid from dried plant material. Thus, there was found to be $0.8 \%$ of phospholipids and $3.6 \%$ of phytin [53].

Qaderi [54] isolated an autoinhibitor of cypsela germination, a derivative of benzamide.

The content of phenols in air-dried achenes, which were extracted by methanol-water, was $2740 \pm 26 \mathrm{mg}$ of gallic acid/100 $\mathrm{g}$ of achenes [55].

\section{Pharmacological Research}

Extracts and individual substances from different parts of $O$. acanthium were investigated in vitro, in vivo, and in silico.

\subsection{In Silico}

Sharifi [20] isolated an inhibitor of ACE from achenes of O. acanthium, (E)-1-oxo-3,4-dihydro-1 H-isochromen-7-yl 3-(3,4-dihydroxyphenyl) acrylate as a yellow powder in the amount of $70 \mathrm{mg}$ from $100 \mathrm{~g}$ of achenes. Activity of this compound was detected on the substrate hippuryl-L-histidyl-L-leucine (HHL). ACE hydrolyzes HHL on hippuric acid (HA). The amount of HA was measured by reversed-phase high-performance liquid chromatography (RP-HPLC). Inhibitor activity was measured based on the area under curve (AUC) of HA peak and expressed as ACE inhibition (\%). The activity of the compound at the concentration of $330 \mu \mathrm{g} / \mathrm{mL}$ was $83 \pm 1 \%$. IC 50 was $300 \pm 25 \mu \mathrm{M}$ as measured using a dose-response curve by nonlinear regression. Pharmacokinetics were determined by the absorption, distribution, metabolism, and excretion (ADME) method in Accelrys Discovery Studio 2.1 (BIOVIA, San Diego, CA, USA). The compound is highly soluble in water, has low blood-brain-barrier penetration, is well absorbed in the intestine, has more than $95 \%$ of association with plasma proteins and does not inhibit cytochrome P450. Molecular docking was performed in AutoDock4.2 (The Scripps Research Institute, La Jolia, CA, USA). There were C- and N- domains of ACE such as targets from the RCSB (the Research Collaboratory for Structural Bioinformatics) Protein Data Bank. The lowest binding energy of the C-domain was $-8.31 \mathrm{kcal} / \mathrm{mol}$, and the lowest binding energy for the $\mathrm{N}$-domain was $-8.29 \mathrm{kcal} / \mathrm{mol}$. 
The compound was named "onopordia". Furthermore, by the method of fluorescence in vitro, the researchers tested onopordia specific activity against ACE domains; a pharmacophoric model of interaction between onopordia and the $\mathrm{N}$-domain was created for the screening of new $\mathrm{ACE}$ inhibitors. Fluorescent assay was used for measuring ACE inhibitor activity. ACE hydrolyzes substrates Abz-SDK (Dnp)P-OH (o-Aminobenzoic acid-Ser-Asp-Lys(DNP)P-OH trifluoroacetate salt) and Abz-LFK (Dnp)-OH (O-Aminobenzoic acid-Leu-Phe-Lys(DNP)-OH trifluoroacetate salt, which specifically interact with the $\mathrm{N}$ - and C-domain, respectively. When ACEs are inhibited, there are increased amounts of Ac-SDKP (N-acetyl-seryl-aspartyl-lysylproline). Additionally, there are decreased fluorescent by-products of hydrolyze ACE. $\mathrm{IC}_{50}$ was measured for the C-domain $(244 \pm 9.0 \mu \mathrm{M})$ and for the $\mathrm{N}$-domain $(180 \pm 1.8 \mu \mathrm{M})$. The results were compared with those for captopril ( $\mathrm{IC}_{50} 2.81 \pm 0.07 \mathrm{nM}$ for the C-domain and $0.9 \pm 0.06 \mathrm{nM}$ for the $\mathrm{N}$-domain). The presence of hydroxyl groups in the phenolic ring are the main markers for $\mathrm{N}$-domain inhibitors. The acrylate double bond and the isochroman-1-one ring are the main markers for C-domain inhibitors $[55,56]$.

\subsection{In vitro}

Extracts and individual compounds present anti-inflammatory, antiradical, antiproliferative, and antibacterial activities.

\subsubsection{Anti-Inflammatory Activity}

The anti-inflammatory action of hexane and methanol extracts from achenes described below should be connected with the presence of arctiin and isochlorogenic acid [29]. Hexane and methanol extracts were identified. Paraffins were identified in hexane extract. Methanol extract was found to contain arctiin (arctigenin-4'-O-D-glucoside), arctigenin, and isochlorogenic acid by gas chromatography mass-spectrometry (GC-MS), high-performance liquid chromatography-mass spectrometry (HPLC-MS), high-performance liquid chromatography-ultraviolet (HPLC-UV) and proton nuclear magnetic resonance $\left({ }^{1} \mathrm{H}-\mathrm{NMR}\right)$ methods. Anti-inflammatory activity was detected on the immortalized human umbilical vein endothelial cells (HUVECtert). These cells were stimulated by lipopolysacharids and tumor necrosis factor-alpha (TNF- $\alpha$ ). Decreased secretion of E-selectin by HUVECtert was measured by real-time quantitative reverse transcription polymerase chain reaction (RT-PCR) and decreased production of interleukin-8 (IL-8) was measured by enzyme-linked immunosorbent assay (ELISA). Furthermore, inhibitory activity of methanol extract on the secretion of E-selectin was detected, as was inhibitory activity of methanol and hexane extracts on the expression of E-selectin. No anti-inflammatory activity was detected by extracts when inflammation was stimulated by TNF- $\alpha$. Methanol extract at a dose of $15-40 \mathrm{mg} / \mathrm{mL}$ or arctiin at a dose of $20-75 \mu \mathrm{M}$ demonstrated inhibitory activity on E-selectin. The positive control was (E)-3-(4-Methylphenylsulfonyl)-2-propenenitrile (BAY 11-7082, an inhibitor of cytokine-induced IкB- $\alpha$ phosphorylation) at a dose of $5 \mu \mathrm{M}$.

Lajter [24] investigated the anti-inflammatory activity of lignans, flavonoids, and sesquiterpene lactones from the aerial part and roots of $O$. acanthium on different targets such as activity on the expression of cyclooxygenase-2 (COX-2) and nuclear factor kappa-light-chain-enhancer of activated B cells (NF- $\mathrm{kB} 1$ ), and its inhibitory effect on the production of NO, 5-lipoxygenase (5-LOX,) COX-1, and COX-2. The positive controls were quercetin $(25 \mu \mathrm{M})$ and dexamethasone $(2.5 \mathrm{nM})$ in the analysis of expression of NF- $\mathrm{kB} 1$ and COX-2; $\mathrm{N}^{\mathrm{G}}$-monomethyl-L-arginine (L-NMMA) as inhibitor of NO-syntase $(100 \mu \mathrm{M})$; zileuton as inhibitor of 5-LOX $(5 \mu \mathrm{M})$; indomethacin and NS-398 (N-[2-(Cyclohexyloxy)-4-nitrophenyl]methanesulfonamide) as inhibitors of COX-1 and COX-2 (1.25 $\mu \mathrm{M}$ and $5 \mu \mathrm{M}$, respectively). Also, hexane, chloroform, and aqueous-methanol extracts from aerial parts and roots were investigated at a dose of $10 \mu \mathrm{g} / \mathrm{mL}$ (inhibition of COX-2 and NF- $\mathrm{kB} 1$ expression and NO-syntase) and $50 \mu \mathrm{g} / \mathrm{mL}$ (inhibition of 5-LOX, COX-1, and COX-2). Individual compounds were investigated at a dose of $20 \mu \mathrm{M}$ dissolved in dimethyl suldoxide (DMSO). The results are presented as inhibition $\% \pm$ SD (Table 6). 
Table 6. The anti-inflammatory activity of the extracts and compounds from aerial parts and roots of O. acanthium L. (Lajter [24]).

\begin{tabular}{|c|c|c|c|c|c|}
\hline \multirow{2}{*}{$\begin{array}{c}\text { Parts of } \\
\text { O. acanthium }\end{array}$} & \multirow{2}{*}{ Extracts/Compound } & $\operatorname{COX}-2^{2}$ & $5-\mathrm{LOX}^{3}$ & NO-syntase & $\mathrm{COX}-1^{1}$ \\
\hline & & \multicolumn{4}{|c|}{ Inhibition (\%) } \\
\hline \multirow{10}{*}{ Aerial parts } & Hexane & 82.8 & & & \multirow{10}{*}{16.2} \\
\hline & Aqueous-methanol & & 31.2 & & \\
\hline & Chloroform & & & 76.7 & \\
\hline & Pinoresinol & & & 49.13 & \\
\hline & Medioresinol & & & & \\
\hline & Syringaresinol & & 28.5 & & \\
\hline & Hispidulin & & 51.6 & & \\
\hline & Nepetin & & 62.4 & & \\
\hline & Apigenin & & 41.3 & & \\
\hline & Luteolin & & 74.6 & & \\
\hline \multirow{9}{*}{ Roots } & Hexane & 86.5 & & \multirow{9}{*}{$\begin{array}{c}100.4 \\
99.4 \\
61.4\end{array}$} & \\
\hline & Aqueous-methanol & & 59.7 & & \\
\hline & Chloroform & & 56.7 & & \\
\hline & $4 \beta, 15$-Dihydro-3-dehydrozaluzanin C & & & & \\
\hline & Zaluzanin C & & & & \\
\hline & $4 \beta, 15,11 \beta, 13$-Tetrahydrozaluzanin C & & & & \\
\hline & Nitidanin diisovalerianate & & 16.1 & & \\
\hline & 13-Oxo-9Z,11E-octadecadienoic acid & & 20.4 & & \\
\hline & 24-Methylenecholesterol & 36.4 & & & \\
\hline
\end{tabular}

The compounds of roots $4 \beta, 15$-Dihydro-3-dehydrozaluzanin $C$ and zaluzanin $C$ were also tested for inhibitory activity of the expression of COX-2 and NF-kB1. The most active on the expression of NF- $\mathrm{KB} 1$ was found to be $4 \beta, 15$-Dihydro-3-dehydrozaluzanin C (inhibition of $96.0 \%$ for a dose of $10 \mu \mathrm{M}$ ), which was also found to be the most active inhibitor of COX-2 (inhibition of $91.2 \%$ on dose $10 \mu \mathrm{M})$. Zaluzanin $C$ was demonstrated to have an inhibition of $83.7 \%$ for the expression of NF-KB1 and an inhibition of $87.9 \%$ for the expression of COX-2. The positive controls were found to have an inhibition of $47.6 \%$ for the expression of COX-2 (dexamethasone at a dose of $2.5 \mathrm{nM}$ ) and an inhibition of $46.0 \%$ for the expression of NF- $\mathrm{kB} 1$ (quercetin at a dose of $25 \mu \mathrm{M}$ ). In XTT viability assay (colorimetric assay by using 2,3-bis-(2-methoxy-4-nitro-5-sulfophenyl)-2H-tetrazolium-5-carboxanilide as a substrate which is reduced to purple formazan in living cells) at different concentrations at four, 24, 48 and $72 \mathrm{~h}$ ), these compounds were demonstrated to have low cytotoxicity [24].

Onopordopicrin decreases intestinal inflammation [33]. Zaluzanin C and estafiatone showed an inhibitory effect on the lipopolysaccharide (LPS)/interferon- $\gamma$ (INF- $\gamma$ )-induced nitric oxide (NO) and prostaglandin E2 $\left(\mathrm{PGE}_{2}\right)$ production on the RAW 264.7 macrophages with $\mathrm{IC}_{50}$ of $6.61 \mu \mathrm{M}$ and $3.80 \mu \mathrm{M}$, respectively. Additionally, suppression of expression inducible NO syntaze (iNOS) and COX-2 was detected. Zaluzanin C inhibits electron and proton transport and inhibits the synthesis of ATP [33].

\subsubsection{Antitumor Activity}

Abuharfeil [57] investigated aqueous extract of leaves and stems of $O$. acanthium against YAC cells (virus-induced murine T-cell lymphoma). The extract increased natural killer cell (NK) activity of splenic lymphoid cells, which exhibit a cytotoxic effect on YAC cells. There were 13 aqueous extracts. Extract from $O$. acanthium showed medium stimulation activity. The activity of aqueous extract from fresh material was $40.6 \%$ (ratio of effector:target 200:1), and that of aqueous extract from air-dried material was $30.4 \%$. The positive control was interferon $\alpha$ at a dose of $500 \mathrm{U} / \mathrm{mL}$, which increased the activity of NK cells by $78.5 \%$.

Csupor-Löffler [58] investigated the antitumor activity of aqueous and organic extracts of 26 plants belonging to tribes Cynareae and Lactuceae (Asteraceae) on cell cultures: HeLa (cervix epithelial adenocarcinoma), A431 (skin epidermoid carcinoma), and MCF7 (breast epithelial adenocarcinoma). Living cells were detected in colorimetric MTT assay using [3-(4,5-dimethylthiazol- 
2-yl)-2,5-diphenyltetrazolium bromide. There were water, n-hexane, chloroform, and aqueous methanol extracts from mixture of flowers and fruits, leaves, and roots of $O$. acanthium. The most active was chloroform extract from leaves at a dose of $30 \mu \mathrm{g} / \mathrm{mL}$ (HeLa: $\mathrm{IC}_{50} 6.53 \mu \mathrm{g} / \mathrm{mL}$, MCF7: IC 50 $6.39 \mu \mathrm{g} / \mathrm{mL}, \mathrm{A} 431: \mathrm{IC}_{50} 4.54 \mu \mathrm{g} / \mathrm{mL}$ ) and roots (HeLa: $\mathrm{IC}_{50} 6.11 \mu \mathrm{g} / \mathrm{mL}, \mathrm{MCF} 7: \mathrm{IC}_{50} 4.39 \mu \mathrm{g} / \mathrm{mL}$, A431: $\mathrm{IC}_{50} 10.32 \mu \mathrm{g} / \mathrm{mL}$ ). The positive controls were doxorubicin (half maximal effective concentration (EC 50 ) HeLa: $0.081 \mu \mathrm{g} / \mathrm{mL}$; MCF7: $0.152 \mu \mathrm{g} / \mathrm{mL}$; A431: $0.081 \mu \mathrm{g} / \mathrm{mL}$ ), cisplatin $\left(\mathrm{IC}_{50} \mathrm{HeLa}: 3.7 \mu \mathrm{g} / \mathrm{mL}\right.$; MCF7: $2.8 \mu \mathrm{g} / \mathrm{mL}$; A431: $0.85 \mu \mathrm{g} / \mathrm{mL}$ ). The most active compounds from O. acanthium roots, 4 $\beta, 15$-Dihydro-3-dehydrozaluzanin C and zaluzanin C [24], were measured for their cytotoxic activity by XTT viability assay. The positive control was vinblastine $(0.1 \mu \mathrm{g} / \mathrm{mL})$. In the XTT viability assay THP-1 cells (human monocytic cell line) were used. These compounds had no or low effect on cell line.

Methanol extracts from leaves of O. acanthium and flowers of Spartium junceum L. (Fabaceae) were compared to each other on the human glioblastoma U-373 cell line. Methanol extract from O. acanthium was measured to have inhibitor activity of $\mathrm{IC}_{50} 309 \mu \mathrm{g} / \mathrm{mL}$, while methanol extract from S. junceum was found to have inhibitor activity of $\mathrm{IC}_{50} 1602 \mu \mathrm{g} / \mathrm{mL}$. This activity was measured by the trypan blue exclusion test. The mechanism of cytotoxicity is connected with inducing caspase-3, a cell enzyme of apoptosis. Thus, methanol extract of O. acanthium leaves showed proapoptotic activity [59].

Molnar [60] connected the antitumor activity of extracts of $O$. acanthium with effect on apoptotic enzymes. Sesquiterpene lactones from herb of Artemisia asiatica and roots of O. acanthium were investigated on the HL-60 cells (human leukemia cell). The compound from roots of $O$. acanthium $4 \beta, 15$-dihydro-3-dehydrozaluzanin $\mathrm{C}$ demonstrated inhibitor activity of $\mathrm{IC}_{50} 3.6 \mu \mathrm{M}$. Cytotoxicity was measured by colorimetric MTT assay, and effects on the cell cycle were investigated by flow cytometric analysis. Cell changes were detected by staining cell DNA with the fluorescent marker propidium iodide and Hoechst 33258 (2'-(4-hydroxyphenyl)-5-(4-methyl-1-piperazinyl)-2,5'-bi-1H-benzimidazole trihydrochloride hydrate). The mechanism of cytotoxicity was inducing mitochondrial pathway of apoptosis by activation of caspase- 3 and caspase- 9 .

The activity of caspase-3 was measured by fluorimetric assay using Ac-DEVD-AMC (N-AcetylAspartyl-Glutamyl-Valyl-Aspartyl-7-amino-4-methylcoumarin) as a substrate. The activity of caspase-9 was measured using Ac-LEHD-pNA (N-Acetyl-Leucyl-Glutamyl-Histidyl-Aspartyl-p- Nitroanilide) as a substrate.

The lactones increased the amount of cells in G1 and G2/M populations, and decreased the amount of cells in the S population. After $48 \mathrm{~h}$ of incubation, an increased number of the hypodiploid (subG1) population was also detected for 5 and $10 \mu \mathrm{M}$ doses. However, $4 \beta, 15$-dihydro-3-dehydrozaluzanin $C$ showed the lowest activity on this population. Compound $4 \beta, 15$-dihydro-3-dehydrozaluzanin $C$ demonstrated inducing activity on the caspase- 3 and caspase- 9 .

Natural compounds that have $\alpha$-methylen- $\gamma$-lactone in their structure may be potential antitumor agents.

NK activity was measured for human blood cells against K562 cells (human immortalized myelogenous leukemia cell line). The activity was tested after treatment with plant extract in the presence of IL-2 $(1000 \mathrm{U} / \mathrm{mL})$ and in the absence of IL-2. Production of cytokines IFN $\gamma$ and TNF $\alpha$ was measured by ELISA; the activity of the cell enzymes granzyme A ( $\mathrm{N}$-alpha-benzyloxycarbonyl-L-lysine thiobenzyl ester (N-BLT) serine esterase) and $\mathrm{N}$-acetyl- $\beta$-D-glucosaminidase (NAG) was measured by spectrophotometric analysis at $405 \mathrm{~nm}$. In the presence of water extract from leaves and stems of O. acanthium, cytotoxicity at a dose of $0.1 \mathrm{mg} / \mathrm{mL}$ (dilution 1:50) of NK cells against K562 cells was $41.3 \%$ in the ratio effector:target of 200:1. In the presence of IL-2 this activity was $56.5 \%$. Synthesis of cytokines after treatment with $0.1 \mathrm{mg} / \mathrm{mL}$ of water extracts in the presence of IL-2 was increased by $60 \%$ for TNF $\alpha$ and $87 \%$ for IFN $\gamma$. The activity of the cell enzymes granzyme A and NAG was measured only for water extracts from seeds of Nigella sativum [61].

Sesquiterpene lactones also demonstrate antitumor activity [33]. Thus, onopordopicrin has cytotoxic activity against the $\mathrm{KB}$ cell line (HeLa derivative). Onopordopicrin has an antiproliferative effect with an $\mathrm{IC}_{50}$ of $15 \mu \mathrm{M}$ on the HL60 (promyelocytic leukemia). Cytotoxic effect was detected against cell 
lines P388 (murine leukemia), A549 (adenocarcinomic human alveolar basal epithelial cells), and HT29 (human colon cancer cell line). This effect connects with the presence of the $\alpha$-methylene- $\gamma$-lactone group. Cytotoxic activity is increased by the presence of additional $\alpha, \beta$-unsaturated ester group.

Arctiopicrin has cytotoxic activity on cell line of the colon cancer cell line in MTT colorimetric experiment. Toxic effects were investigated by brine shrimp lethality assay.

Zaluzanin C showed a cytotoxic effect on cell lines such as A549, SK-OV-3 (ovarian cancer cell line), SK-MEL-2 (human melanoma cell line), XF498 (human central nervous system (CNS) cancer), HCT15 (human colon adenocarcinoma), HL60, P388, HepG2 (human liver cancer cell line), HeLa, and OVCAR-3 (human ovarian carcinoma cell line). The effects of this compound on peptide synthesis inhibit the translocation of peptidyl-tRNA.

Zaluzanin $C$ and estafiatone inhibit the proliferation of T- and B lymphocytes of mice with dose of $1 \times 10^{-5} \mathrm{M}$ or lower.

\subsubsection{Antiradical Activity}

There are different data about the antioxidant activity of $O$. acanthium.

Kiselova [62] tested 23 aqueous plant extracts; for O. acanthium, air-dried flowers were used. In water extract, amounts of polyphenols were measured as $\mu \mathrm{M}$ quercetin equivalents. Antioxidant activity was measured by ABTS (2,2'-azinobis(3-ethylbenzothiazoline-6-sulfonic acid)) cation radical decolorization assay. In the presence of potassium persulfate, ABTS radical has absorbance at $734 \mathrm{~nm}$ that decreased if water extract contains some antioxidants. Flowers of O. acanthium demonstrated low antioxidant activity: $0.44 \pm 0.06 \mathrm{mM}$ Trolox equivalent antioxidant capacity (TEAC). The highest activity was $4.79 \pm 0.14 \mathrm{mM}$ TEAC by water extract from herb of Alchemilla vulgaris L.; the lowest activity was $0.31 \pm 0.01 \mathrm{mM}$ TEAC by water extract from flowers of Calendula officinalis L. The positive controls were the plants Camellia sinensis (L.) Kuntze, Ilex paraguariensis A.St.-Hil., Aspalathus linearis (Burm.f.) R.Dahlgren, and Cyclopia intermedia E.Mey.

Sharifi [20] carried out experiment using 2,2-diphenyl-1-picrylhydrazyl (DPPH). DPPH assay was based on the decreasing absorbance of DPPH solution at $517 \mathrm{~nm}$ then DPPH connection with radicals. Methanol extract of achenes of $O$. acanthium was demonstrated to have $\mathrm{IC}_{50} 2.6 \pm 0.04 \mu \mathrm{g} / \mathrm{mL}$. The positive controls were 6-hydroxy-2,5,7,8-tetramethylchroman-2-carboxylic acid (Trolox) and butylated hydroxytoluene (BHT), which had IC $503.3 \pm 0.06 \mu / \mathrm{mL}$ and $\mathrm{IC}_{50} 10.3 \pm 0.15 \mu / \mathrm{mL}$, respectively.

In [55], the antioxidant activity of water-methanol extracts from air-dried achenes of $O$. acanthium was found to be $\mathrm{IC}_{50} 7.0 \pm 0.09 \mu \mathrm{g} / \mathrm{mL}$. The positive controls were BHT $\left(\mathrm{IC}_{50} 10.3 \pm 0.15 \mu / \mathrm{mL}\right.$ ) and Trolox $\left(\mathrm{IC}_{50} 3.2 \pm 0.06 \mu / \mathrm{mL}\right)$.

Koc [21] measured the antioxidant activity of methanol, ethanol, and acetone extracts from the flowers and leaves of O. acanthium using DPPH. The total phenolic content was investigated using Folin-Ciocalteu's reagent, which consists of hexavalent phosphomolybdic/phosphotungstic acid complexes. This reagent is connected with hydroxyl groups of phenols and products have absorbance at $765 \mathrm{~nm}$. Furthermore, authors researched the inhibitor effect on the antioxidant enzymes such as catalase (CAT), glutathione S-transferase (GST), and glutathione peroxidase (GPx). Free-radical scavenging activity was measured as $\mathrm{IC}_{50}$ and was calculated from the dose-response inhibition curve. Acetone extract had IC $50842 \mathrm{ng} / \mathrm{mL}$, ethanol extract $\mathrm{IC}_{50} 1120 \mathrm{ng} / \mathrm{mL}$, and methanol extract $\mathrm{IC}_{50} 723 \mathrm{ng} / \mathrm{mL}$. The positive controls were ascorbic acid, with $\mathrm{IC}_{50} 5.144 \mu \mathrm{g} / \mathrm{mL}$, and quercetin, with $\mathrm{IC}_{50} 1.685 \mu \mathrm{g} / \mathrm{mL}$. Extracts from O. acanthium materials did not show high inhibitory activity of antioxidant enzymes.

Similar research was conducted by Habibatni [22], using DPPH and butanol extract from leaves of $O$. acanthium. Antioxidant activity was measured as $\mathrm{IC}_{50} 134.4 \mathrm{mg} / \mathrm{mL}$. The positive control was ascorbic acid ( $\mathrm{IC}_{50} 21.4 \mu \mathrm{g} / \mathrm{mL}$ ) and the negative control was a solution of DDPH in $80 \%$ methanol without $O$. acanthium extract. Additionally, authors investigated the hypouricemic effect as an inhibitor of xanthine oxidase. This experiment was carried out using the absorbance of products of xanthine and xanthine oxidase (the dose of xanthine oxidase was $0.1 \mathrm{U} / \mathrm{mL}$ ). The positive control was allopurinol. 
The activity of butanol extract was $7.0 \%$ of inhibition at a dose of $100 \mu \mathrm{g} / \mathrm{mL}$, and its $\mathrm{IC}_{50}$ was $572.9 \mu \mathrm{g} / \mathrm{mL}$, while allopurinol had $\mathrm{IC}_{50} 3.9 \mu \mathrm{g} / \mathrm{mL}$.

\subsubsection{Antibacterial Activity}

Methanol extract from the aerial part of $O$. acanthium at a concentration of $100 \mu \mathrm{g} / \mathrm{mL}$ had no antibacterial effect on several cultures: Klebsiella pneumonia, Proteus vulgaris, Shigella sonnei, Vibrio cholerae, Escherihia coli, Staphylococcus aureus, Bacillus anthracis, and Salmonella paratyphi A [63].

The antibacterial effect of methanol extract from achenes of $O$. acanthium was investigated using the gram-negative cultures Escherichia coli and Klebsiella pneumonia and the gram-positive cultures Staphylococcus epidermidis, S. aureus, and Micrococcus luteus by agar disc diffusion method. The reference control was amikacin at a dose of $30 \mathrm{mg}$. The highest antibacterial effects were on the culture of M. luteus, with a diameter of zone inhibitor of $21 \pm 1 \mathrm{~mm}$, and on the culture of S. epidermidis $(18.66 \pm 1.53 \mathrm{~mm})$. There was no inhibitory activity against $S$. aureus, K. pneumonia, or E. coli. Minimum inhibitory concentration (MIC) was measured by the broth macro dilution method and resazurin microtiter method. For the second method, kanamycin was used as the positive control. MICs were obtained for S. epidermidis and M. luteus $(0.612 \mathrm{mg} / \mathrm{mL})$. The total phenolic content was found to be $168.56 \pm 4.89 \mathrm{mg}$ of gallic acid/g of extract [64].

Ethyl acetate extract from fresh leaves of $O$. acanthium was investigated for antibacterial activity after dissolution in 10-times crude extract in ethanol. The extract was separated by TLC and offline overpressure layer chromatography (OPLC) direct bioautography. The most active fractions were analyzed by HPLC-MS. The structure of isolated compounds was detected by NMR. The extract was separated by low-pressure flash chromatography. This work used Allivibrio fischeri, Bacillus subtilis strain F1276, Pseudomonas syringae pv. maculicola, Xanthomonas euvesicatoria, Lactobacillus plantarum, S. aureus, methicillin resistant $S$. aureus (MRSA), and E. coli. The MIC was also measured for extracts between $27.6-275.9 \mu \mathrm{g} / \mathrm{mL}$ and for isolated onopordopicrin between $2.2-172.4 \mu \mathrm{g} / \mathrm{mL}$ by a broth microdilution method. In the results after TLC analysis, inhibitor activity of growth B. subtilis was found. There were two zones, one with a retardation factor $\left(h R_{\mathrm{f}}\right)$ of 37 and one with an $h R_{\mathrm{f}}$ of 82 . The zone with $\mathrm{hR}_{\mathrm{f}} 82$ was active against $B$. subtilis, X. euvesicatoria, A. fischeri, S. aureus, and MRSA. All of the bacterial cultures were sensitive to component $\mathrm{hR}_{\mathrm{f}} 37$; however $P$. maculicola was inhibited by a high amount of this compound. Onopordopicrin inhibited all of the bacterial cultures; however P. maculicola was resistant to $20 \mu \mathrm{g}$ onopordopicrin [35].

Estafiatone has antibacterial activity against $B$. subtilis. Zaluzanin $C$ inhibits root and shoot growth in lettuce, tomatoes, and cress, and has antifungal activity. Additionally, onopordopicrin demonstrated antibacterial activity against $S$. aureus [33].

\subsubsection{Antihypertensive Activity}

In Iran, the screening of 50 plants was carried out in the presence ACE-inhibitor activity [55]. Air-dried achenes of $O$. acanthium $(1 \mathrm{~g})$ were extracted by $20 \mathrm{~mL}$ of methanol-water $(80: 20 \mathrm{v} / \mathrm{v})$ at room temperature for $24 \mathrm{~h}$ followed by $2 \mathrm{~h}$ in an ultrasonic bath. The extract was filtered, concentrated under low pressure at room temperature, and then lyophilized. ACE-inhibitor activity was detected using HHL as a substrate. After hydrolyzing HHL by ACE, hippuric acid (HA) is produced. The amount of HA was measured by RP-HLPC. Inhibitor activity for the extract from O. acanthium achenes was $80.2 \pm 2.0 \%$.

\subsection{In vivo}

\subsubsection{Anti-Inflammatory Activity}

Ivanova [65] investigated the activity of ethanol extract from herb of O. acanthium using two models: cotton pellet-induced granuloma model and caoline-induced paw edema model. In the first model, cotton pellets were implanted in the backs of rats, and removed after eight days. The increase 
in the dry weight of the pellets was taken as a measure of granuloma formation. In the caoline-induced model, animals were given subplantar injection of $0.1 \mathrm{~mL} 10 \%$ caoline. The raw volume was measured four hours, one day, and two days after the injection. Ethanol extracts at doses of 0.25 and $0.84 \mathrm{mg} / \mathrm{kg}$ were input orally, while the control group received saline; the negative control was $40 \%$ ethanol at a dose of $0.25 \mathrm{~mL} / \mathrm{kg}$ and $0.84 \mathrm{~mL} / \mathrm{kg}$. In the cotton pellet-induced granuloma model, extract at the dose of $0.25 \mathrm{mg} / \mathrm{mL}$ decreased edema in the exudative and proliferative steps, while at the dose of $0.84 \mathrm{mg} / \mathrm{mL}$ the main effect was in the exudative stage. In the caoline model, the effect of the dose of $0.84 \mathrm{mg} / \mathrm{mL}$ was higher than that for the dose of $0.25 \mathrm{mg} / \mathrm{mL}$.

Anti-inflammatory activity may be related to the presence of triterpenoids. Taraxasterol and taraxasteryl acetate were extracted by chloroform from leaves and flowers of $O$. acanthium and were then separated by column chromatography using silica gel. Taraxasterol and its derivatives showed activity in formaline-induced edema model albino rats. Percentile edema inhibition was measured in terms of paw thickness. Inflammation was induced by subplantar injection of $0.1 \mathrm{~mL}$ of $3 \%$ formaline. The control group was orally administered saline $30 \mathrm{~min}$ before the injection. The positive control was prednisolone administered orally at a dose of $10 \mathrm{mg} / \mathrm{kg} 30 \mathrm{~min}$ before formaline injection. Taraxasterol was administered orally at a dose of $10 \mathrm{mg} / \mathrm{kg} 30 \mathrm{~min}$ before the formaline injection. In the results, taraxasterol was found to decrease inflammation by $38.2 \%$ after three hours and by $31.4 \%$ after $24 \mathrm{~h}$. Meanwhile, prednisolone decreased inflammation by $35.3 \%$ after three hours and by $32.6 \%$ after $24 \mathrm{~h}$. In the control group, inflammation decreased by $41.2 \%$ after three hours and by $41.8 \%$ after $24 \mathrm{~h} \mathrm{[66].}$

Habibatni [22] investigated extracts of methanol, hexane, chloroform, ethyl acetate, and butanol from O. acanthium leaves for cytotoxicity using Artemia salina leach. The lowest cytotoxic effect was observed for the butanol extract. The anti-inflammatory activity of the butanol extract was researched by carrageenan-induced edema model on four groups of six Wistar rats. The positive control received $100 \mathrm{mg} / \mathrm{mL}$ of aspirin orally one hour before an injection of $0.1 \mathrm{~mL}$ of $0.6 \%$ carrageenan. The negative control received $0.9 \%$ saline orally one hour before an injection of $0.1 \mathrm{~mL}$ of $0.6 \%$ carrageenan. In the results, inflammation was inhibited by $37.78 \%$ by a dose of $200 \mathrm{mg} / \mathrm{kg}$ of butanol extract and by $40.52 \%$ by a dose of $400 \mathrm{mg} / \mathrm{kg}$ of butanol extract. Aspirin at a dose of $100 \mathrm{mg} / \mathrm{kg}$ decreased inflammation by $42.62 \%$.

\subsubsection{Antipyretic Activity}

The antipyretic effect of butanol extract of $O$. acanthium leaves has been tested on rats [22]. Animals received subcutaneous injection of a pyrogenic dose of brewer's yeast $20 \%$ ( $1 \mathrm{~mL} / 100 \mathrm{~g}$ body weight). The basal temperature was measured rectally every hour for five hours. The positive control was aspirin administered orally at a dose of $500 \mathrm{mg} / \mathrm{mL}$ and the negative control was water administered orally. Butanol extract was administered at doses of 200 and $400 \mathrm{mg} / \mathrm{mL}$ orally. The basal temperature was $36.38^{\circ} \mathrm{C}$. After five hours of injection, the body temperature was $39.5^{\circ} \mathrm{C}$ in the control group. Aspirin decreased body temperature to $37.22^{\circ} \mathrm{C}$. In the group treated with butanol extract at a dose of $200 \mathrm{mg} / \mathrm{mL}$, body temperature was $37.38^{\circ} \mathrm{C}$, while in the group treated with $400 \mathrm{mg} / \mathrm{mL}$ of butanol extract, body temperature was decreased to $37.34^{\circ} \mathrm{C}$.

\subsubsection{Analgesic Activity}

Analgesic activity was detected by abdominal cramps in mice $30 \mathrm{~min}$ after intraperitoneal injection of $1 \%$ acetic acid. The positive control was $500 \mathrm{mg} / \mathrm{kg}$ aspirin administered orally $30 \mathrm{~min}$ before the injection of acetic acid. The negative control was saline administered $30 \mathrm{~min}$ before injection of acetic acid. Butanol extract was administered at doses of 200 and $400 \mathrm{mg} / \mathrm{kg} 30 \mathrm{~min}$ before injection of acetic acid. The analgesic effect was measured as a percentage decrease in cramps. For the dose of $200 \mathrm{mg} / \mathrm{kg}$ of butanol extract, this decrease was $72.0 \%$, while for the dose of $400 \mathrm{mg} / \mathrm{kg}$ it was $76.57 \%$; in the positive group, the decrease in cramps was $86.29 \%$ [22]. 


\subsubsection{Toxicity}

Female BALB/C mice were treated with water herbal extracts from 20 different plants instead of water for three weeks. Their blood was haematologically tested each week (haemoglobin, hematocrit, amount of white blood cells) and biochemical tests were conducted (glucose, urea, cholesterol, creatinine, direct and total bilirubin). All extracts were safe. Then, the activity of NK cells was measured during four weeks of oral treatment with the water extracts. Each week, the spleen was isolated and splenic lymphoid cells were tested for NK activity against YAC cells. In the results, water extract from fresh leaves and stems of $O$. acanthium induced NK activity after one week of treatment at 38.6\% at an effector:target ratio of 200:1. For the mixture of water extracts with high and medium activity (seeds of $N$. sativum, leaves and stems of $O$. Acanthium, bulb of Allium sativum and Allium cepa), after one week of treatment the NK activity was increased by $65.3 \%$ at an effector:target ratio of 200:1 [67].

Additionally, toxicity was investigated in the male mice. Dry extract from achenes of O. acanthium was dissolved in DMSO and injected intraperitoneally. Animals' condition (lethargy and movement) and animal death were investigated for $24-48 \mathrm{~h}$. At a dose of $0.5-5 \mathrm{~g} / \mathrm{kg}$ of animal weight, there was no change in the condition or deaths of mice. At a dose of $20 \mathrm{~g} / \mathrm{kg}$, all animals died. Lethal Dose, 50\% $\left(\mathrm{LD}_{50}\right)$ was $8.44 \pm 0.04 \mathrm{~g} / \mathrm{kg}$. Extract from the cypsela of O. acanthium was described as "practically nonpoisonous" [68].

\subsubsection{Regeneration Effect}

Hydroalcoholic extract from flowers of $O$. acanthiumin was used in in vivo experiments on female and male rabbits for the treatment of wounds. There were five groups of seven animals. Animals were shaved in the dorsal area. Then, a wound $2 \times 2 \mathrm{~cm}$ in size was cut by a metal plate. Animals were anaesthetized by subcutaneous injection of $2 \mathrm{~mL}$ of $2 \%$ lidocaine. The area of the wound was measured by placing a transparent film over graph paper. The extract was dissolved to produce the $0.1-1 \%$ ointment with eucerin (lanolin, water, oil) as an ointment base. The ethanol extract was prepared from leaves, stems, flowers, and roots using $70 \%$ ethanol. The most effective was found to be flower extract administered at doses of $0.0025,0.05,0.1,0.2$, and $0.4 \%(\mathrm{w} / \mathrm{w})$. The optimum concentration was $0.2 \%$ and the maximum regeneration was at six days after extract administration. The minimum time for $50 \%$ of wound treatment was 3.2 days. The control group was treated with eucerin and $50 \%$ of wound area was treated after 7.2 days [69].

\subsubsection{Antihypertensive Effect}

Patients between 30-60 years in age were involved in an investigated group treated by capsules with $1 \mathrm{~g}$ of dry extract from seeds of $O$. acanthium from $11 \mathrm{~g}$ air-dried achenes extracted by ethanol $(1: 8)$, and the extract was evaporated and prepared in capsules. Patients with stage I-II hypertension (blood pressure higher then 140/90 $\mathrm{mmHg}$ ) were treated with $50 \mathrm{mg}$ /day losartan six weeks before the experiments. They were then administered with two capsules two times a day for eight weeks. Arterial blood pressure was measured each week and metabolic parameters (lipid profile, liver function tests, blood urea nitrogen, chromium, fasting blood sugar) were measured two times before and after treatment. In clinical experiments, the base systolic blood pressure of $151.9 \pm 13.74 \mathrm{mmHg}$ was decreased to $134.6 \pm 18.25 \mathrm{mmHg}$ at the end of the therapy. Diastolic blood pressure, which was originally $97.41 \pm 10.36 \mathrm{mmHg}$, had decreased to $85.71 \pm 7.481 \mathrm{mmHg}$ at the end of therapy. There were no changes in the metabolic parameters [68].

A summary of pharmacological properties of extracts and individual compounds can be found in Table 7. 
Table 7. Summary of the effects of extracts and individual compounds from Onopordum acanthium L.

\begin{tabular}{|c|c|c|c|c|}
\hline Part of plant & Extract/compound & Activity & Method & Reference \\
\hline \multirow[t]{2}{*}{ Aerial part } & $\begin{array}{l}\text { hexane, aqueous-methanol, } \\
\text { chloroform/pinoresinol, medioresinol, } \\
\text { syringaresinol, hispidulin, nepetin, } \\
\text { apigenin, luteolin }\end{array}$ & \multirow[t]{2}{*}{ anti-inflammatory } & $\begin{array}{l}\left.\text { activity on the expression of COX-2 and NF-kB1 }{ }^{1} \text { (real-time PCR }{ }^{2}\right) \text {, inhibitory effect on the } \\
\text { production of NO (Griess assay method), } 5 \text {-LOX }\left(\text { EIA }^{3}\right), \text { COX-1, and COX-2 (EIA }{ }^{3} \text { ) }\end{array}$ & [24] \\
\hline & ethanol & & cotton pellet-induced granuloma model and caoline-induced paw edema model per rats & [65] \\
\hline \multirow{12}{*}{ Leaves } & \multirow[b]{3}{*}{ aqueous } & \multirow{5}{*}{ antitumor, cytotoxicity } & $\begin{array}{l}\text { NK }{ }^{4} \text { activity of splenic lymphoid cells isolated from spleens of eight- to } 10 \text {-week-old } \\
\text { BALB/C female mice. Splenic cells provide cytotoxic effect on } \text { YAC }^{5} \text { cells detected by } \\
\qquad{ }^{51} \text { Cr-release assay }\end{array}$ & [57] \\
\hline & & & $\begin{array}{l}\text { activity of NK }{ }^{4} \text { cells from human peripheral blood against } \mathrm{K}^{2} 62^{6} \text { cells by staining viable } \\
\text { cells with neutral red solution; production of cytokines IFN } \gamma^{7} \text { and TNF } \alpha^{8} \text { by ELISA }{ }^{9}\end{array}$ & {$[61]$} \\
\hline & & & $\begin{array}{l}\text { the toxicity of aqueous extract was measured on eight- to } 10 \text {-week-old BALB/C female } \\
\text { mice. The blood was haematologically tested each week (haemoglobin, hematocrit, amount } \\
\text { of white blood cells) and biochemical tests were performed (glucose, urea, cholesterol, } \\
\text { creatinine, direct and total bilirubin). NK }{ }^{4} \text { activity of splenic lymphoid cells isolated from } \\
\text { BALB/C mice spleen those were treated by plant extract for three weeks. Splenic cells have } \\
\text { a cytotoxic effect on YAC }{ }^{5} \text { cells detected by }{ }^{51} \text { Cr-release assay }\end{array}$ & [67] \\
\hline & methanol & & trypan blue exclusion test using cell culture U-373 ${ }^{10}$ & [59] \\
\hline & \multirow{2}{*}{ chloroform } & & MTT ${ }^{11}$ assay using cell cultures: $\mathrm{HeLa}^{12}, \mathrm{~A}^{1} 31^{13}$, and MCF7 ${ }^{14}$ & [58] \\
\hline & & anti-inflammatory & formaline-induced edema model per albino rats & [66] \\
\hline & methanol. ethanol, acetone & antiradical & DPPH ${ }^{15}$ antioxidant assay & [21] \\
\hline & ethyl acetate & antibacterial & $\begin{array}{l}\text { gram-negative cultures Allivibrio fischeri, Pseudomonas syringae pv. maculicola, Xanthomonas } \\
\text { euvesicatoria, and Escherichia coli; gram-positive cultures Bacillus subtilis strain F1276, } \\
\text { Lactobacillus plantarum, Staphylococcus aureus, and methicillin resistant S. aureus (MRSA) by } \\
\text { TLC } 16 \text { and OPLC }{ }^{17} \text { direct bioautography }\end{array}$ & [35] \\
\hline & \multirow{4}{*}{ butanol } & antiradical & $\mathrm{DPPH}^{15}$ antioxidant assay & \multirow{4}{*}{ [22] } \\
\hline & & anti-inflammatory & carrageenan-induced edema model on four groups per six Wistar rats & \\
\hline & & antipyretic & decrease of pyretic effect induced by injection of brewer's yeast $20 \%$ to rats & \\
\hline & & analgesic & abdominal cramps in mice $30 \mathrm{~min}$ after intraperitoneal injection of $1 \%$ acetic acid & \\
\hline
\end{tabular}


Table 7. Cont.

\begin{tabular}{|c|c|c|c|c|}
\hline Part of plant & Extract/compound & Activity & Method & Reference \\
\hline \multirow[t]{3}{*}{ Stems } & \multirow[t]{3}{*}{ aqueous } & \multirow[t]{3}{*}{ antitumor } & $\begin{array}{l}\mathrm{NK}^{4} \text { activity of splenic lymphoid cells isolated from spleens of eight- to } 10 \text {-week-old } \\
\text { BALB/C female mice. Splenic cells exert a cytotoxic effect on the YAC }{ }^{5} \text { cells detected by } \\
{ }_{51}^{51} \text { Cr-release assay }\end{array}$ & [57] \\
\hline & & & $\begin{array}{l}\text { activity of NK }{ }^{4} \text { cells from human peripheral blood against K562 }{ }^{6} \text { cells by staining viable } \\
\text { cells with neutral red solution; production of cytokines IFN } \gamma^{7} \text { and TNF } \alpha^{8} \text { by ELISA }{ }^{9}\end{array}$ & [61] \\
\hline & & & $\begin{array}{l}\text { the toxicity of aqueous extract was measured on eight- to } 10 \text {-week-old BALB/C female } \\
\text { mice. The blood was haematologically tested each week at (haemoglobin, hematocrit, } \\
\text { amount of white blood cells) and biochemical tests were conducted (glucose, urea, } \\
\text { cholesterol, creatinine, direct and total bilirubin). NK }{ }^{4} \text { activity of splenic lymphoid cells } \\
\text { isolated from BALB /C mice spleen those were treated by plant extract for three weeks. } \\
\text { Splenic cells exert a cytotoxic effect on YAC }{ }^{5} \text { cells detected by }{ }^{51} \text { Cr-release assay }\end{array}$ & [67] \\
\hline \multirow{3}{*}{ Inflorescences } & aqueous & \multirow{2}{*}{ antiradical } & ABTS ${ }^{18}$ antioxidant assay & [62] \\
\hline & methanol. ethanol, acetone & & $\mathrm{DPPH}^{15}$ antioxidant assay & [21] \\
\hline & ethanol & regeneration & $0.2 \%$ ointment with base eucerin using female and male rabbits treated for wounds & [69] \\
\hline \multirow{4}{*}{ Achenes } & methanol/arctiin, isochlorogenic acid & anti-inflammatory & real-time PCR $^{2}$ and ELISA ${ }^{9}$ using cell culture HUVECtert ${ }^{19}$ & [29] \\
\hline & \multirow{2}{*}{$\begin{array}{l}\text { water-methanol/(E)-1-oxo-3,4-dihydro-1 } \\
\text { H-isochromen-7-yl } \\
\text { 3-(3,4-dihydroxyphenyl) acrylate } \\
\text { ("onopordia") }\end{array}$} & antiradical & DPPH $^{15}$ antioxidant assay & {$[20,55]$} \\
\hline & & $\begin{array}{c}\text { inhibitor of } \\
\text { angiotensin-converting enzyme } \\
\text { (ACE) }\end{array}$ & $\begin{array}{l}\text { RP-HLPC }{ }^{20} \text {, molecular docking, fluorescent assay; treatment of } 20 \text { patients between } \\
30-60 \text { years in age with stage I-II hypertension by capsules with } 1 \mathrm{~g} \text { of dry extract for } \\
\text { eight weeks }\end{array}$ & {$[20,55,68]$} \\
\hline & methanol & antibacterial & $\begin{array}{l}\text { gram-negative cultures Escherichia coli and Klebsiella pneumonia and gram-positive cultures } \\
\text { Staphylococcus epidermidis, Staphylococcus aureus, and Micrococcus luteus byagar disc } \\
\text { diffusion method }\end{array}$ & [64] \\
\hline \multirow[t]{3}{*}{ Roots } & $\begin{array}{c}\text { hexane, aqueous-methanol, } \\
\text { chloroform/4 } \beta, 15 \text {-Dihydro-3-dehydrozal } \\
\text { C, zaluzanin C, } \\
4 \beta, 15,11 \beta, 13 \text {-Tetrahydrozaluzanin C, } \\
\text { nitidanin diisovalerianate, } \\
\text { 13-Oxo-9Z,11E-octadecadienoic acid, } \\
\text { 24-methylenecholesterol }\end{array}$ & $\begin{array}{l}\text { uzanin } \\
\text { cytotoxic, anti-inflammatory }\end{array}$ & $\begin{array}{l}\text { XTT }{ }^{20} \text { viability assay, activity on the expression of COX-2 and NF-kB } 1^{1} \text { (real-time PCR }{ }^{2} \text { ), } \\
\left.\text { inhibitory effect on the production of NO (Griess assay method), 5-LOX (EIA }{ }^{3}\right), \text { COX-1 }^{-1} \text { and } \\
\left.\text { COX-2 (EIA }{ }^{3}\right)\end{array}$ & [24] \\
\hline & chloroform & \multirow{2}{*}{ antitumor } & MTT ${ }^{11}$ assay using cell cultures: $\mathrm{HeLa}^{12}, \mathrm{~A} 431^{13}, \mathrm{MCF}^{14}$ & [58] \\
\hline & $4 \beta, 15$-dihydro-3-dehydrozaluzanin C & & MTT $^{11}$ assay using cell culture HL- $60^{22}$ & {$[60]$} \\
\hline $\begin{array}{l}{ }^{1} \text { Nuclear fac } \\
{ }^{6} \text { Human im } \\
\text { line, } 11 \text { [3- }(4, \\
15 \text { 2,2-diphen } \\
\text { human umb } \\
{ }^{22} \text { Human let }\end{array}$ & $\begin{array}{l}\text { kappa-light-chain-enhancer of activa } \\
\text { rtalised myelogenous leukemia cell } 1 \\
\text { limethylthiazol-2-yl)-2,5-diphenyltetr } \\
\text { 1-picrylhydrazyl, } 16 \text { Thin layer chroma } \\
\text { al vein endothelial cells, }{ }^{20} \text { Reversed- } \\
\text { mia cells }\end{array}$ & $\begin{array}{l}\text { d B cells, }{ }^{2} \text { Polymerase chain } \\
\text { ee, }{ }^{7} \text { Interferon gamma, }{ }^{8} \mathrm{Tu} \\
\text { zolium bromide, } 12 \text { Cervix } \\
\text { ography, }{ }^{17} \text { Offline overpress } \\
\text { hase high-performance liqu }\end{array}$ & $\begin{array}{l}\text { action, }{ }^{3} \text { Enzyme immuno assay, }{ }^{4} \text { Natural killer cells, }{ }^{5} \text { Virus-induced murine T cell } \\
\text { or necrosis factor-alpha, }{ }^{9} \text { Enzyme-linked immunosorbent assay, }{ }^{10} \text { Human gliob } \\
\text { thelial adenocarcinoma, }{ }^{13} \text { Skin epidermoid carcinoma, }{ }^{14} \text { Breast epithelial aden } \\
\text { e layer chromatography, }{ }^{18} \text { 2, } 2 \text { '-azinobis(3-ethylbenzothiazoline-6-sulfonic acid, }{ }^{19} \text { In } \\
\text { chromatography, }{ }^{21} \text { 2,3-bis-(2-methoxy-4-nitro-5-sulfophenyl)-2H-tetrazolium-5-ca }\end{array}$ & $\begin{array}{l}\text { mphoma, } \\
\text { toma cell } \\
\text { arcinoma, } \\
\text { cortalized } \\
\text { oxanilide, }\end{array}$ \\
\hline
\end{tabular}




\section{Conclusions}

The traditional usage of the aerial part of Onopordum acanthium, which is an edible plant, a source of honey, and an anti-inflammatory, antitumor, and cardiotonic remedy, demonstrates the safety and non-toxicity of this plant. Research demonstrates that $O$. acanthium is a potential preventive and medicinal plant. Extracts from the herb, leaves, seeds, and individual substances such as sesquiterpene lactones, triterpenoids, lignans, etc., have anti-inflammatory, antiproliferative, and antihypertensive properties. These effects may be used in the treatment of chronic inflammation and to prevent various types of tumors. The presence of sesquiterpene lactones in the roots and the presence of triterpenoids in the aerial part correlate with antitumor and anti-inflammatory properties of extracts. More detailed study of chemical content, systematic in vitro and in vivo tests, and comparative study of O. acanthium and related species such as O. illyricum L., Carduus nutans L., and Cirsium vulgare (Savi) Ten. may be useful work.

Author Contributions: E.R.G. searched for articles in PubMed, ScienceDirect, Mendeley, ResearchGate, GoogleScholar, analyzed these data, and wrote the review. D.A.K. developed the methodology of the article, and edited the review. A.A.S. designed and prepared Tables and Figures. M.P.G. formatted references. K.K.O. edited the final review.

Funding: This research received no external funding.

Acknowledgments: Authors acknowledge Pyatigorsk Medical-Pharmaceutical Institute (PMPI), Branch of Volgograd State Medical University, Ministry of Health of Russia, Pyatigorsk, Russian Federation and South Kazakhstan State Pharmaceutical Academy, Shymkent, Kazakhstan.

Conflicts of Interest: The authors declare no conflict of interest.

\section{Abbreviations}

The following abbreviations are used in this manuscript:

$\begin{array}{ll}{ }^{13} \text { C-NMR } & \text { Carbon-13 nuclear magnetic resonance } \\ { }^{1} \mathrm{H}-\mathrm{NMR} & \text { Proton nuclear magnetic resonance } \\ 5 \text {-LOX } & \text { 5-lipoxygenase } \\ \text { ACE } & \text { Angiotensin-converting enzyme } \\ \text { COX-1 } & \text { Cyclooxygenase-1 } \\ \text { COX-2 } & \text { Cyclooxygenase-2 } \\ \text { DMSO } & \text { Dimethyl suldoxide } \\ \text { DNA } & \text { Deoxyribonucleic acid } \\ \text { EC } 50 & \text { Half maximal effective concentration } \\ \text { EIA } & \text { Enzyme immuno assay } \\ \text { ELISA } & \text { Enzyme-linked immunosorbent assay } \\ \text { GC-MS } & \text { Gas chromatography mass-spectrometry } \\ \text { HPLC-MS } & \text { High-performance liquid chromatography-mass Spectrometry } \\ \text { HPLC-UV } & \text { High-performance liquid chromatography-ultraviolet } \\ \text { hR } & \text { Retardation factor } \\ \text { IC } & \text { Half maximal inhibitory concentration } \\ \text { IL-2, IL-8 } & \text { Interleukin-2, interleukin-8 } \\ \text { INF- } \gamma & \text { Interferon gamma } \\ \text { IR } & \text { Infrared } \\ \text { LD } & \text { Lethal dose, 50\% } \\ \text { LPS } & \text { Lipopolysaccharide } \\ \text { NF-kB1 } & \text { Nuclear factor kappa-light-chain-enhancer of Activated B cells } \\ \text { NK } & \text { Natural killer cells } \\ \text { NMR } & \text { Nuclear magnetic resonance } \\ \text { NO } & \text { Nitrogen oxide } \\ & \end{array}$




$\begin{array}{ll}\text { OPLC } & \text { Offline overpressure layer chromatography } \\ \text { PGE }_{2} & \text { Prostaglandin E2 } \\ \text { RP-HPLC } & \text { Reversed-phase high-performance liquid chromatography } \\ \text { RT-PCR } & \text { Reverse transcription polymerase chain reaction } \\ \text { SD } & \text { Standart deviation } \\ \text { TLC } & \text { Thin layer chromatography } \\ \text { TNF- } \alpha & \text { Tumor necrosis factor-alpha } \\ \text { U } & \text { Units }\end{array}$

\section{References}

1. Grieve, M. A Modern Herbal: The Medicinal, Culinary, Cosmetic and Economic Properties, Cultivation and Folk-lore of Herbs, Grasses, Fungi, Shrubs, E Trees with All Their Modern Scientific Uses; Courier Corporation: Mineola, NY, USA, 2014; Volume 2, ISBN -13.

2. The Plant List, the Royal Botanic Gardens, Kew and Missouri Botanical Garden. Available online: http: / / www.theplantlist.org (accessed on 17 October 2018).

3. Tahtadjan, A.L. The system of magnoliophytes; Nauka: Leningrad, USSR, 1986; 439 p.

4. The Integrated Taxonomic Information System. Available online: https://www.itis.gov (accessed on 17 October 2018).

5. Byng, J.W.; Chase, M.W.; Christenhusz, M.J.M.; Fay, M.F.; Judd, W.S.; Mabberley, D.J.; Sennikov, A.N.; Soltis, D.E.; Soltis, P.S.; Stevens, P.F. An update of the Angiosperm Phylogeny Group classification for the orders and families of flowering plants: APG IV. Bot. J. Linn. Soc. 2016, 181, 1-20. [CrossRef]

6. Tutin, T.G.; Heywood, V.H.; Burges, N.A.; Moore, D.M.; Valentine, D.H.; Walters, S.M.; Webb, D.A. Flora Europaea: Plantaginaceae to Compositae (and Rubiaceae); Cambridge University Press: Cambridge/London, UK, 1976; Volume 4, p. 505. ISBN 05210877171.

7. Cavers, P.B.; Qaderi, M.M.; Threadgill, P.F.; Steel, M.G. The Biology of Canadian Weeds. 147. Onopordum acanthium L. Can. J. Plant Sci. 2011, 91, 739-758. [CrossRef]

8. Lim, T.K. Edible Medicinal And Non-Medicinal Plants; Springer: Dordrecht, The Netherlands, 2014; Volume 7, ISBN 978-94-007-7394-3.

9. Mobli, M.; Qaraaty, M.; Amin, G.; Haririan, I.; Hajimahmoodi, M.; Rahimi, R. Scientific evaluation of medicinal plants used for the treatment of abnormal uterine bleeding by Avicenna. Arch. Gynecol. Obstet. 2015, 292, 21-35. [CrossRef] [PubMed]

10. Mamedov, N.A.; Mehdiyeva, N.P.; Craker, L.E. Medicinal plants used in traditional medicine of the Caucasus and North America. J. Med. Active Plants 2015, 4, 42-66. [CrossRef]

11. Berendes, J. Des Pedanois Dioskurides aus Anazarbos Arzneimittellehre in Fünf Büchern; Ferdinand Enke: Stuttgard, Germany, 1902.

12. Pharmacopoea Rossica; Petropoli. 1782. Available online: https://books.google.ru/books?id= uL2rvC5GRvMC\&dq=Pharmacopoea+Rossica\&hl=ru\&source=gbs_navlinks_s (accessed on 17 October 2018).

13. Zhou, J.; Xie, G.; Yan, X. Encyclopedia of Traditional Chinese Medicines - Molecular Structures, Pharmacological Activities, Natural Sources and Applications; Springer: Berlin, Germany, 2011; Volume 6, p. 619. ISBN 978-3-642-16734-8.

14. Mariani, E.; Donarini, C.; Grampella, D.; Guerrerio, T.; Landoni, G.; Portalupi, E. Integrated treatment of cardiovascular common pathologies with conventional pharmacological therapy integrated with a typical remedy of anthroposophic medicine, Cardiodoron (Onopordon/Primula comp). Eur. J. Integr. Med. 2009, 1, 230. [CrossRef]

15. Cysarz, D.; Schürholz, T.; Bettermann, H.; Kümmell, H.-C. Evaluation of modulations in heart rate variability caused by a composition of herbal extracts. Arzneimittel-Forschung 2000, 50, 420-424. [CrossRef] [PubMed]

16. Cysarz, D.; Heckmann, C.; Kümmell, H.C. The effects of Cardiodoron ${ }^{\circledR}$ on cardio-respiratory coordination-a literature review. Forsch. Komplementarmed. Klass. Naturheilkd. 2002, 9, 292-297. [CrossRef] [PubMed]

17. Rother, C. Administration of Cardiodoron ${ }^{\circledR}$ in patients with functional cardiovascular disorders and/or sleep disorders-results of a prospective, non-interventional study. Forsch. Komplementarmed. 2013, 20, 334-344. [CrossRef] [PubMed]

18. Rother, C.; Schnelle, M. Cardiodoron ${ }^{\circledR}$ in Patients with Sleep Disorders-Results of a Prospective Observational Study. Complementary Med. Res. 2017, 24, 15-25. [CrossRef] 
19. Gatuline ${ }^{\circledR}$ Skin-Repair Bio. Available online: https://www.gattefosse.com/gatuline-skin-repair-bio (accessed on 17 October 2018).

20. Sharifi, N.; Souri, E.; Ziai, S.A.; Amin, G.; Amini, M.; Amanlou, M. Isolation, Identification and Molecular Docking Studies of a New Isolated Compound, from Onopordon acanthium: A Novel Angiotensin Converting Enzyme (ACE) inhibitor. J. Ethnopharmacol. 2013, 148, 934-939. [CrossRef]

21. Koc, S.; Isgor, B.S.; Isgo, Y.G.; Moghaddam, N.S.; Yildirim, O. The potential medicinal value of plants from Asteraceae family with antioxidant defense enzymes as biological targets. Pharm. Biol. 2015, 53, 746-751. [CrossRef] [PubMed]

22. Habibatni, S.; Zohra, A.F.; Khalida, H.; Anwar, S.; Mansi, I.; Awadh Ali, N.A. In-vitro antioxidant, Xanthine oxidase-inhibitory and in-vivo Anti-inflammatory, analgesic, antipyretic activity of Onopordum acanthium. Int. J. Phytomed. 2017, 9, 92-100. [CrossRef]

23. Karl, C.; Mueller, G.; Pedersen, P.A. Zur Phytochemie der Blüten von Onopordon acanthium L. (Eselsdistel). Dtsch. Apoth. Ztg. 1976, 116, 57-59.

24. Lajter, I.; Pan, S.P.; Nikles, S.; Ortmann, S.; Vasas, A.; Csupor-Löffler, B.; Forgó, P.; Hohmann, J.; Bauer, R. Inhibition of COX-2 and NF-kB1 Gene Expression, NO Production, 5-LOX, and COX-1 and COX-2 Enzymes by Extracts and Constituents of Onopordum acanthium. Planta Med. 2015, 81, 1270-1276. [CrossRef] [PubMed]

25. Lajter, I. Biologically active secondary metabolites from Asteraceae and Polygonaceae species. Ph.D. Thesis, University of Szeged, Szeged, Hungary, 2015.

26. Watanabe, Y.; Novaes, P.; Varela, R.M.; Molinillo, J.M.G.; Kato-Noguchi, H.; Macías, F.A. Phytotoxic Potential of Onopordum acanthium L. (Asteraceae). Chem. Biodivers. 2014, 11, 1247-1255. [CrossRef] [PubMed]

27. Bogs, H.U.; Bogs, U. Constituents of Onopordum acanthium. L. Coumarins and flavones. Pharmazie 1965, 20, 706-709. [PubMed]

28. Bogs, H.U.; Bogs, U. Über die Inhaltsstoffe von Onopordon acanthium L. Pharmazie 1967, 22, 54-58.

29. Daci, A.; Gold-Binder, M.; Garzon, D.; Patea, A.; Beretta, G. Standardization of solvent extracts from Onopordum acanthium fruits by GC-MS, HPLC-UV/DAD, HPLC-TQMS and ${ }^{1} \mathrm{H}-\mathrm{NMR}$ and evaluation of their inhibitory effects on the expression of IL-8 and E-selectin in immortalized endothelial cells (HUVECtert). Nat. Prod. Commun. 2014, 9, 945-948. [PubMed]

30. Tyumkina, T.V.; Nuriev, I.F.; Khalilov, L.M.; Akhmetova, V.R.; Dzhemilev, U.M. PMR and ${ }^{13}$ C NMR spectra of biologically active compounds. XIII.* Structure and stereochemistry of a new phenylpropanoid glycoside isolated from Onopordum acanthium seeds. Chem. Nat. Compd. 2009, 45, 61-65. [CrossRef]

31. Csupor-Löffler, B.; Zupkó, I.; Molnár, J.; Forgó, P.; Hohmann, J. Bioactivity-guided isolation of antiproliferative compounds from the roots of Onopordum acanthium. Nat. Prod. Commun. 2014, 3, 337-340.

32. Ivanova, L.R.; Butenko, L.I.; Ligai, L.V.; Sbezhneva, V.G. Determination of iridoids in the herb of Onopordum acanthium, genus Onopordum. Chem. Plant. Mater. 2010, 4, 131-133.

33. Bruno, M.; Maggio, A.; Rosselli, S.; Safder, M.; Bancheva, S. The metabolites of the genus Onopordum (Asteraceae): Chemistry and biological properties. Curr. Org. Chem. 2011, 15, 888-927. [CrossRef]

34. Droźdź, B.; Holub, M.; Samek, Z.; Herout, V.; Šorm, F. On terpenes. CXCII. The constitution and absolute configuration of onopordopicrine - a sesquiterpenic lactone from Onopordum acanthium L. Collect. Czech. Chem. C. 1968, 33, 1730-1737. [CrossRef]

35. Móricz, Á.M.; Krüzselyi, D.; Alberti, Á.; Darcsi, A.; Horváth, G.; Csontos, P.; Béni, S.; Ott, P.G. Layer chromatography-bioassays directed screening and identification of antibacterial compounds from Scotch thistle. J. Chromatogr. A 2017, 1524, 266-272. [CrossRef] [PubMed]

36. Khalilova, A.Z.; Shakurova, E.R.; Nuriev, I.F.; Akhmetova, V.R.; Khalilov, L.M.; Dzhemilev, U.M. Triterpenoids of Onopordum acanthium (Asteraceae). Plant. Resour. 2007, 43, 97-102.

37. Khalilov, L.M.; Khalilova, A.Z.; Shakurova, E.R.; Nuriev, I.F.; Kachala, V.V.; Shashkov, A.S.; Dzhemilev, U.M. PMR and ${ }^{13} \mathrm{C}$ NMR spectra of biologically active compounds. XII. Taraxasterol and its acetate from the aerial part of Onopordum acanthium. Chem. Nat. Compd. 2003, 39, 285-288. [CrossRef]

38. Khalilova, A.Z.; Litvinov, I.A.; Beskrovnyi, D.V.; Gubaidullin, A.T.; Shakurova, E.R.; Nuriev, I.F.; Khalilov, L.M.; Dzhemilev, U.M. Isolation and crystal structure of taraxasteryl acetate from Onopordum acanthium. Chem. Nat. Compd. 2004, 40, 254-257. [CrossRef]

39. Ul'chenko, N.T.; Gigienova, É.I.; Abdullaev, U.A.; Umarov, A.U. Nonglyceride complex of the seed oil of Onopordum acanthium. Chem. Nat. Compd. 1979, 15, 533-536. [CrossRef] 
40. Nolasco, S.N.; Bertoni, M.H.; Malec, L.; Cattaneo, Y.P. Seeds of Onopordon acanthium L. (Scotch thistle), Carduus acanthoides L. (plumeless thistle) and Cirsium vulgare (Savi) Ten (bull thistle). Extracted crude oils and seed meals. An. Asoc. Quim. Argent. 1987, 75, 29-34.

41. Arfaoui, M.O.; Renaud, J.; Ghazghazi, H.; Boukhchina, S.; Mayer, P. Variation in oil content, fatty acid and phytosterols profile of Onopordum acanthium L. during seed development. Nat. Prod. Res. 2014, 28, 2293-2300. [CrossRef]

42. Zhelev, I.; Merdzhanov, P.; Angelova-Romova, M.; Zlatanov, M.; Antova, G.; Dimitrova-Dyulgerova, I.; Stoyanova, A. Lipid Composition of Carduus thoermeri Weinm., Onopordum acanthium L. and Silybum marianum L., growing in Bulgaria. Bulg. J. Agric. Sci. 2014, 20, 622-627.

43. Bohlmann, F.; Kohn, S.; Waldau, E. Der Poyine des Subtribus Carduinae. Chem. Ber. 1966, 99, $3201-3203$. [CrossRef]

44. Ul'chenko, N.T.; Gigienova, E.I.; Umarov, A.U. Epoxytriglyceride oils of the seeds of Onopordum acanthium. Chem. Nat. Compd. 1978, 14, 438-439. [CrossRef]

45. Ul'chenko, N.T.; Gigienova, É.I.; Seitanidi, K.L.; Umarov, A.U. The glyceride complex of the seed oil of Onopordum acanthiium. Chem. Nat. Compd. 1978, 14, 595-601. [CrossRef]

46. Gigienova, E.I.; Umarov, A.U. Nonglyceride lipids of the seed coats of Artemisia absinthium and Onopordum acanthium. Chem. Nat. Compd. 1981, 17, 116-118. [CrossRef]

47. Ul'chenko, N.T.; Gigienova, E.I.; Umarov, A.U.; Isamukhamedov, A. Sh. Hydroxy acids of the seed oils of five plants of the family Asteraceae. Chem. Nat. Compd. 1981, 17, 26-30. [CrossRef]

48. Ul'chenko, N.T.; Gusakova, S.D.; Glishenkova, A.I. Oxygenated triacylglycerols of the lipids of Onopordum acanthium seeds. Chem. Nat. Compd. 1993, 29, 578-581. [CrossRef]

49. Matthaus, B.; Ozcan, M.M.; Al-Juhaimi, F. Fatty Acid, Tocopherol, and Mineral Contents of Onopordum acanthium SEED and OIL. Chem. Nat. Compd. 2014, 50, 1092-1093. [CrossRef]

50. Tonguç, M.; Erbaş, S. Evaluation of fatty acid compositions and some seed characters of common wild plant species of Turkey. Turk. J. Agric. For. 2012, 36, 673-679. [CrossRef]

51. Cicin, N.V. Atlas of medicinal plants; State Publishing House of Medicinal Literature: Moscow, USSR, 1962; p. 711.

52. Brown, L.S.R.; Gray, D.O. 1-amino-2-propanol, a natural product from the Compositae. Phytochemistry 1988, 27, 1195-1197. [CrossRef]

53. Muhamedov, H.S.; Acramov, S.T. The content of phospholipids and phytin in seeds of different plants. Chem. Nat. Compd. 1977, 4, 505-507.

54. Qaderi, M.M.; Cavers, P.B.; Bernards, M.A. Isolation and structural characterization of a water-soluble germination inhibitor from Scotch thistle (Onopordum acanthium) achenes. J. Chem. Ecol. 2003, 29, 2425-2438. [CrossRef] [PubMed]

55. Sharifi, N.; Souri, E.; Ziai, S.A.; Amin, G.; Amanlou, M. Discovery of new angiotensin converting enzyme (ACE) inhibitors from medicinal plants to treat hypertension using an in vitro assay. DARU J. Pharm. Sci. 2013, 21, 74. [CrossRef]

56. Sharifi, N.; Khajeh, K.; Mahernia, S.; Balalaie, S.; Ataie, G.; Jahanbani, R.; Amanlou, M. Probing Angiotensin Converting Enzyme (ACE) Domain-Dependent Inhibition of Onopordia, Isolated from Onopordon acanthium L., Using a Continuous Fluorescent Assay. Pharm. Sci. 2018, 24, 31-37. [CrossRef]

57. Abuharfeil, N.M.; Maraqa, A.; Von Kleist, S. Augmentation of natural killer cell activity in vitro against tumor cells by wild plants from Jordan. J. Ethnopharmacol. 2000, 71, 55-63. [CrossRef]

58. Csupor-Löffler, B.; Hajdú, Z.; Réthy, B.; Zupkó, I.; Máthé, I.; Rédei, T.; Falkay, G.; Hohmann, J. Antiproliferative activity of Hungarian Asteraceae species against human cancer cell lines. Part II. Phytother. Res. 2009, 23, 1109-1115. [CrossRef]

59. Abusamra, Y.A.-K.; Scuruchi, M.; Habibatni, S.; Maammeri, Z.; Benayache, S.; D'Ascola, A.; Avenoso, A.; Campo, G.M.; Spina, E. Evaluation of putative cytotoxic activity of crude extracts from Onopordum acanthium leaves and Spartium junceum flowers against the U-373 glioblastoma cell line. Pak. J. Pharm. Sci. 2015, 28, 1225-1232.

60. Molnár, J.; Szebeni, G.J.; Csupor-Löffler, B.; Hajdú, Z.; Szekeres, T.; Saiko, P.; Ocsovszki, I.; Puskás, L.G.; Hohmann, J.; Zupkó, I. Investigation of the Antiproliferative Properties of Natural Sesquiterpenes from Artemisia asiatica and Onopordum acanthium on HL-60 Cells in Vitro. Int. J. Mol. Sci. 2016, 17, 83. [CrossRef] 
61. Shabsoug, B.; Khalil, R.; Abuharfeil, N. Enhancement of natural killer cell activity in vitro against human tumor cells by some plants from Jordan. J. Immunotoxicol. 2008, 5, 279-285. [CrossRef]

62. Kiselova, Y.; Ivanova, D.; Chervenkov, T.; Gerova, D.; Galunska, B.; Yankova, T. Correlation between the In Vitro antioxidant activity and polyphenol content of aqueous extracts from Bulgarian herbs. Phytother. Res. 2006, 11, 961-965. [CrossRef]

63. Surmaghi, M.H.S.; Amin, G. Screening of Iranian plants for antimicrobal activity III. DARU J. Pharm. Sci. 1993, 3, 55-62.

64. Zare, K.; Nazemyeh, H.; Lotfipour, F.; Farabi, S.; Ghiamirad, M.; Barzegari, A. Antibacterial activity and total phenolic content of the Onopordon acanthium L. seeds. Pharm. Sci. 2014, 20, 6-11.

65. Ivanova, L.R.; Lysenko, T.A.; Sbezhneva, V.G.; Ivashev, M.N. Anti-inflammatory activity of extract from herb Onopordum acanthium. Pharmacy 2007, 4, 39-40.

66. Shakurova, E.R.; Parfenova, T.I.; Sufiyarova, R.Sh.; Khalilova, A.Z.; Akhmetova, V.R.; Bashlkatov, S.A. Synthesis and anti-inflammatory activity of acyl derivatives of taraxasterol. Pharm. Chem. J. 2008, 42, 319-321. [CrossRef]

67. Abuharfeil, N.M.; Salim, M.; Von Kleist, S. Augmentation of natural killer cell activity in vivo against tumour cells by some wild plants from Jordan. Phytother. Res. 2001, 15, 109-113. [CrossRef] [PubMed]

68. Ghods, R.; Gharouni, M.; Amanlou, M.; Sharifi, N.; Ghobadi, A.; Amin, G. Effect of Onopordon acanthium L. as Add on Antihypertensive Therapy in Patients with Primary Hypertension Taking Losartan: A Pilot Study. Adv. Pharm. Bull. 2018, 8, 69-75. [CrossRef] [PubMed]

69. Koochek, M.H.; Ghochani, A.; Pipelzadeh, M.H. Effect of Onopordon acanthium on full-thickness dermal wound healing in rabbit. DARU J. Pharm. Sci. 2000, 8, 45-49.

(C) 2019 by the authors. Licensee MDPI, Basel, Switzerland. This article is an open access article distributed under the terms and conditions of the Creative Commons Attribution (CC BY) license (http:/ / creativecommons.org/licenses/by/4.0/). 